\title{
KONDISI BIOLIMNOLOGI SUMBER DAYA PERAIRAN KOLONG BEKAS GALIAN PASIR DI JAWA BARAT DAN KESESUAIANNYA BAGI BUDIDAYA PERIKANAN
}

\author{
Adriani S.N. Krismono ${ }^{*}$, Siti Nuroniah ${ }^{*}$ dan Endi Setiadi Kartamihardja*)
}

\begin{abstract}
ABSTRAK
Badan air yang terbentuk akibat penambangan pasir banyak terdapat di Bekasi dan Tangerang, Jawa Barat. Sampai saat ini perairan tersebut belum dimanfaatkan untuk usaha perikanan. Salah satu informasi penting yang diperlukan dalam rangka pemanfaatan badan air tersebut untuk usaha perikanan adalah kondisi biolimnologinya. Penelitian biolimnologi perairan bekas galian pasir yang bertujuan untuk mengetahui sifat fisika-kimiawi dan kondisi biologi perairan (plankton, bentos, perifiton dan tanaman air), status trofik dan penilaian kelayakannnya untuk usaha perikanan budidaya telah dilakukan di Bekasi dan Tangerang pada bulan Juli, September, November 1995 dan Januari, Februari 1996. Pengambilan sampel air, plankton, bentos, tumbuhan air dan sedimen dasar perairan dilakukan pada beberapa kedalaman. Berdasarkan kondisi biolimnologinya, perairan bekas galian pasir termasuk perairan dengan kesuburan rendah sampai tinggi (oligo sampai dengan hipertrofik), kualitas perairannya termasuk golongan $\mathrm{C}$, sedangkan keragaman plankton kecil, kelimpahan perifiton dan benthos sedang, di beberapa perairan terdapat tumbuhan seperti Ceraptopteris thalictroides, Eichhornia crassipes, Hydrilla verticillata, Ipomoea aquatica, Jussieva sp., Salvinia natans dan Scoparia dulcis. Perairan yang terletak di Sukasari dan Cihuni layak untuk pengembangan perikanan budidaya.
\end{abstract}

ABSTRACT: Biolimnological condition of sand mining pools in West Java and their suitability for fish culture. By: Adriani S.N. Krismono,Siti Nuroniah and Endi Setiadi Kartamihardja.

Water bodies as a result of sand mining were found at Bekasi and Tangerang regencies, West Java presently. Most of these water bodies have not been utilized for culture. A study on biolimnological aspect of the sand mining pools aimed to gather information on physico-chemical properties and biology (plankton, benthos, periphyton and aquatic weeds), trophic status, and evaluation of suitability of the water bodies for fish culture had been conducted at Bekasi and Tangerang regencies on July, September, November 1995 and January, February 1996. Water sample, plankton, benthos, aquatic weeds and bottom sediment were collected at different depths. Based on the result of biolimnological determination, the sand mining pools were classified as oligo to hypertrophic waters. The water quality belonged to C classification, diversity of plankton was low, and had a moderate abundance of periphyton and benthic organism. In some old water bodies, aquatic weeds were also found. The sand mining pools at Sukasari and Cihuni were found to be suitable for fish culture.

KEYWORDS: Biolimnology, sand mining pools, fish culture.

\section{PENDAHULUAN}

Di daerah Jawa Barat terutama di Bekasi dan Tangerang dijumpai beberapa badan air baru yang terbentuk akibat penambangan pasir. Badan air tersebut memiliki ciri-ciri morfologi sebagai berikut: tebing curam; daerah litoral sempit; kedalaman air relatif dangkal 4-12 m; fluktuasi air 1.2 m; wilayah tangkapan (catchment area) sempit; derodon (draw down) kecil; teluknya sedikit; garis pantai pendek; badan air berbentuk elip atau persegi panjang dengan luas berkisar antara 0,5 dan 5 ha, berlokasi di pedesaan. Di Sri Lanka terdapat badan air yang diberi nama "seasonal tank" yang hampir mirip dengan perairan bekas galian tambang pasir di

*) Peneliti pada Balai Penelitian Perikanan Air Tawar 
Bekasi dan Tangerang. Menurut Udawattage dalam de Silva (1988), badan air ini memiliki ciricir sebagai berikut: wilayah tangkapan kecil, kedalaman air sangat dangkal dengan variasi kedalaman 1.4 m, luas rata-rata 12 ha dan lokasi di tengah pedesaan. Ilyas et al. (1989) telah membuat klasifikasi perairan umum di antaranya adalah badan air yang disebut kolong-kolong (water tanks, water pools) yang mirip dengan perairan bekas galian pasir. Badan air yang termasuk kolong-kolong adalah genangan air yang relatif tidak luas terbentuk secara alami atau buatan. Sampai saat ini kolong-kolong tersebut belum banyak dimanfaatkan dan merupakan lahan tidur yang tidak produktif. Pada umumnya setelah dilakukan penambangan pasir, perairan bekas galian tersebut ditinggalkan oleh para penambang tanpa melakukan reklamasi. Salah satu tindakan yang dapat dilakukan untuk optimasi pemanfaatan sumber daya perairan tersebut adalah mengembangkannya untuk usaha perikanan. Upaya tersebut dapat dicapai jika diterapkan IPTEK perikanan yang tepat. Menurut Goldman \& Horne (1983) hal-hal utama pada lingkungan perairan yang perlu diperhatikan antara lain adalah sejarah perairan, pengembangan yang telah ada, variabel alami fisika kimia dan ciri biota yang mendasari komunitas pada ekosistem tersebut. Selanjutnya khususnya dalam rangka pengelolaan perikanan, informasi tentang status trofik atau status nutrien suatu perairan juga sangat diperlukan. Berdasarkan status nutrien, suatu perairan dapat diklasifikasikan dalam tiga kelas yaitu oligotrofik, mesotrofik dan eutrofik. Perairan eutrofik dibagi lagi menjadi empat macam yaitu eutrofik dengan stratifikasi, eutrofik tanpa stratifikasi, politrofik dan hipertrofik (Ryding \& Rast, 1989).

Tujuan penelitian adalah untuk mendapatkan data dan informasi tentang kondisi biolimnologi perairan yakni sifat fisika-kimiawi dan kondisi biologi perairan (plankton, benthos, perifiton dan tanaman air), status trofik dan status kelayakan perairan bekas bahan galian pasir di Jawa Barat untuk budidaya ikan.

\section{BAHAN DAN METODE}

Pengamatan kondisi biolimnologi sumber daya perairan baru bekas galian pasir di Bekasi dan Tangerang (Jawa Barat) telah dilakukan pada bulan Juli, September, November 1995, serta
Januari dan Februari 1996. Menurut data dari Badan Meteorologi dan Geofisika di Bekasi dan Tangerang, bulan-bulan pengamatan termasuk dalam klasifikasi sebagai berikut:

$\begin{array}{ll}\text { Juli dan September: } & \begin{array}{l}\text { bulan kering/musim } \\ \text { kemarau }\end{array} \\ \text { November: } & \begin{array}{l}\text { bulan peralihan/musim } \\ \text { peralihan }\end{array}\end{array}$

Januari dan Februari: bulan basah/musim hujan

Pengamatan dilaksanakan pada tujuh buah perairan yang berada di tujuh desa yang merupakan daerah pantai dan memiliki ketinggian 7-60 m.dpl (Tabel 1 dan Gambar 1). Metode pengamatan adalah metode survai dengan pengambilan sampel pada beberapa kedalaman. Untuk setiap lokasi pengamatan dilakukan pengambilan sampel pada kedalaman: $0,1,2,4,5,6,7,8,9,10$ dan 12 meter.

Metode untuk menentukan kualitas air menggunakan sistem nilai dari US EPA (Siregar, 1992). Parameter kualitas air yang digunakan adalah suhu air, total padatan terlarut, $\mathrm{pH}, \mathrm{O}_{2}$, $\mathrm{CO}_{2}, \mathrm{~N}-\mathrm{NO}_{2}$ dan N-NH . Hasilnya kemudian dibandingkan dengan kriteria baku mutu air bagi perikanan untuk menentukan kualitasnya. Metode US EPA membagi kualitas air dalam empat (4) kelas yaitu:

Kelas A : baik sekali, skor 0

Kelas B : baik, skor -1 sampai -10

Kelas C : sedang, skor -11 sampai -30

Kelas D : buruk, skor $>-31$

Penentuan status trofik perairan menggunakan metode Ryding \& Rast (1989). Parameter yang digunakan adalah: $\mathrm{O}_{2}, \mathrm{~N}-\mathrm{NO}_{3}, \mathrm{~N}-\mathrm{NO}_{2}$, $\mathrm{N}-\mathrm{NH}_{4}, \mathrm{~N}-\mathrm{NH}_{3}, \mathrm{P}_{-} \mathrm{PO}_{4}$, total P, klorofil-a dan kecerahan. Berdasarkan besarnya konsentrasi atau tingkat kejenuhan parameter yang diukur, perairan diklasifikasikan menjadi perairan: oligotrofik (kualitas kelas 1), mesotrofik (kualitas kelas 2), eutrofik dengan stratifikasi (kualitas kelas 3a), eutrofik tanpa stratifikasi (kualitas kelas 3b), politrofik (kualitas kelas 4) dan hipertrofik (kualitas kelas 5). Masing-masing status trofik dengan kelas tertentu dan masing-masing parameter memiliki nilai tertentu. 


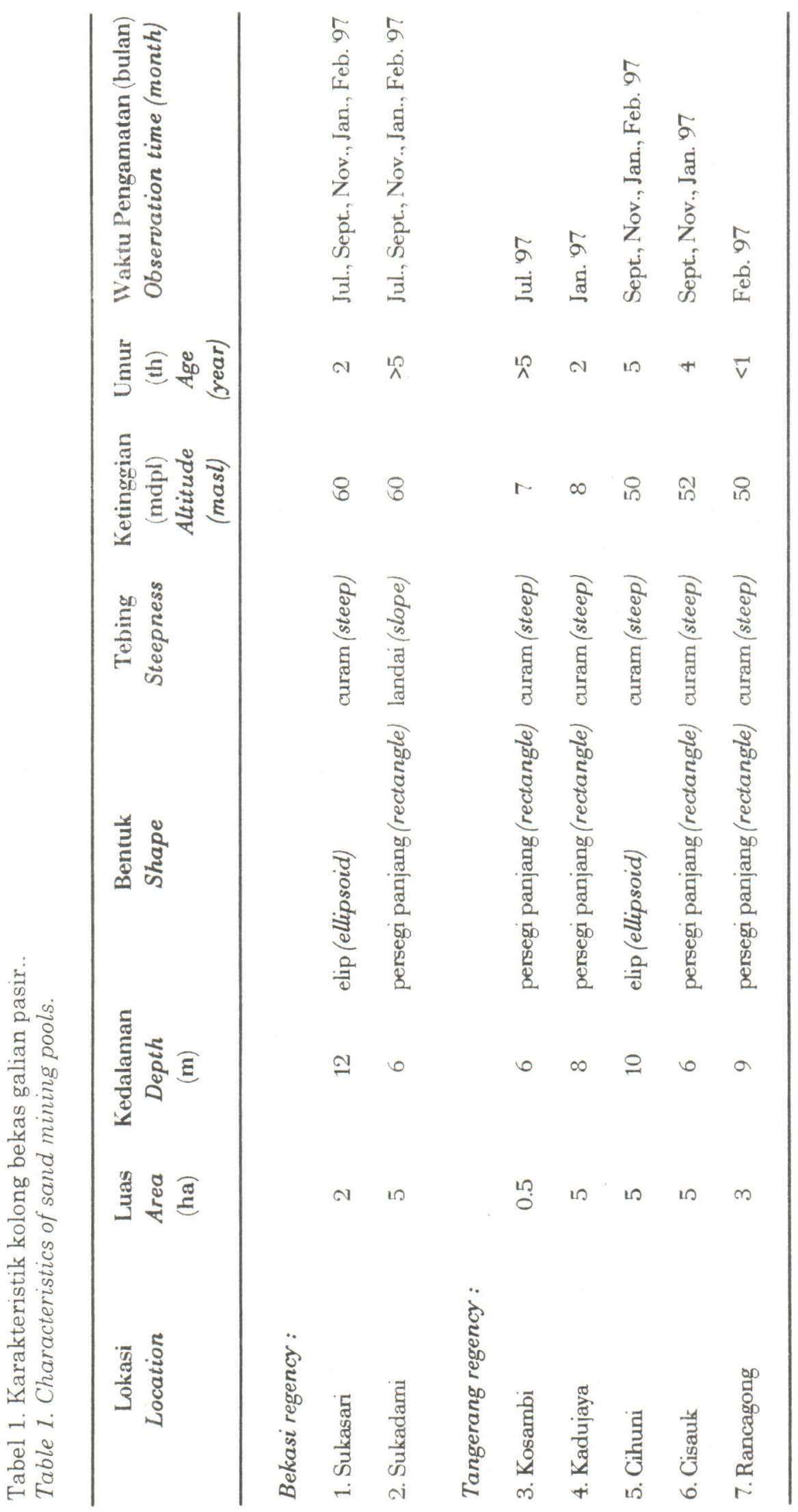




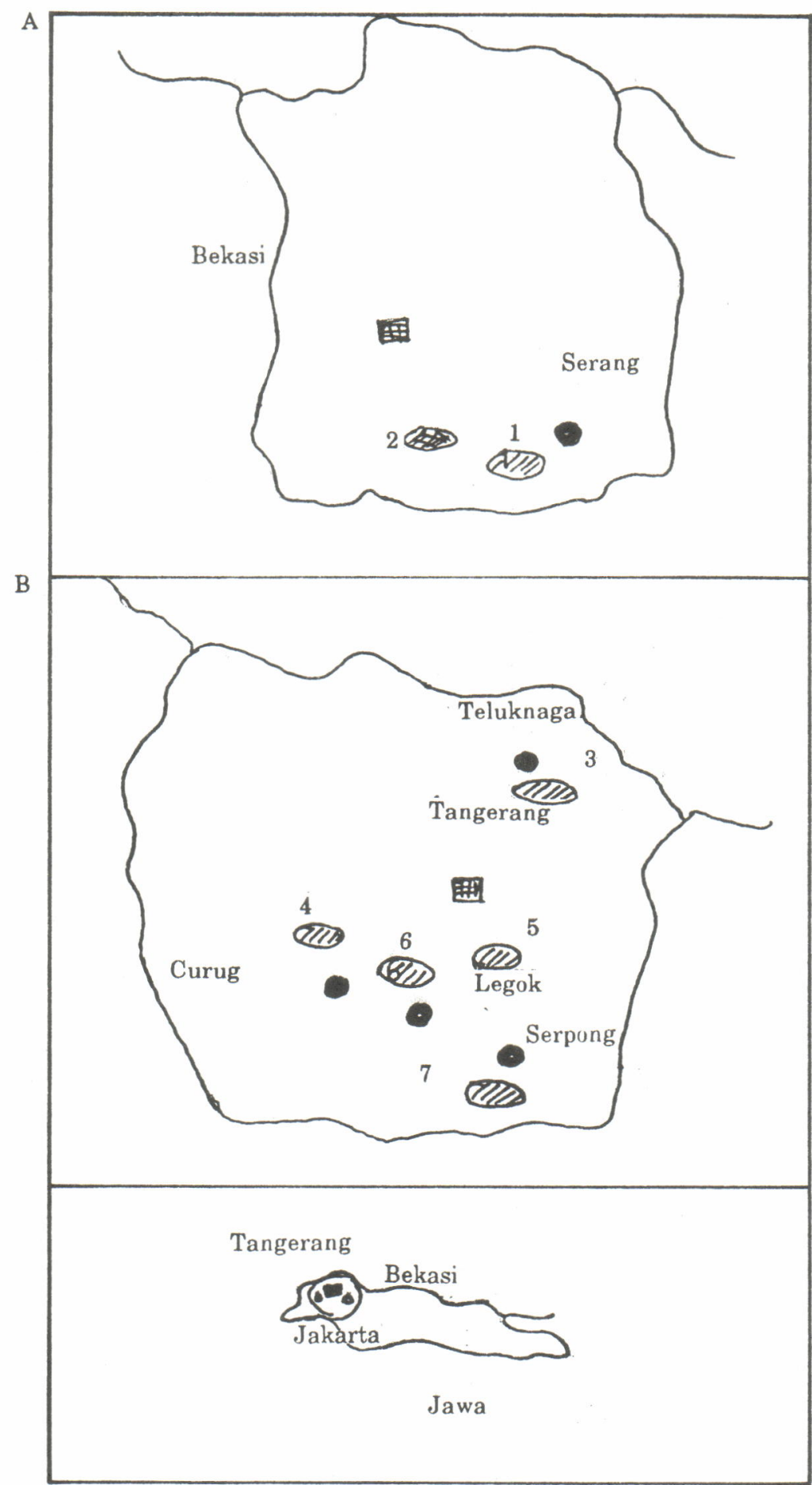

Keterangan (Legend):

1. Sukadami

2. Sukasari

3. Kosambi

4. Kadujaya

5. Cihuni

6. Rancagong

7. Cisauk

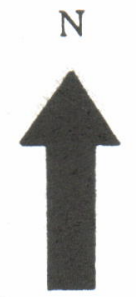

Skala $1: 200.000$

Gambar 1. Peta lokasi pengamatan di Bekasi (A) dan Tangerang (B), Jawa Barat Figure 1. Map of observation in Bekasi (A) and Tangerang (B) regencies, West Java 


\section{HASIL DAN PEMBAHASAN}

\section{Fisika-Kimiawi Air}

Warna air di beberapa perairan yang diamati hijau cerah, hijau gelap dan cokelat. Warna hijau cerah di perairan Sukasari (Bekasi) dan Cihuni (Tangerang). Warna hijau pekat di perairan Kosambi dan cokelat di perairan Sukadami (Bekasi), Cisauk, Kadujaya serta Rancagong (Tangerang). Warna perairan di pengaruhi jenis materi yang tersedia dalam air. Warna hijau cerah dan pekat lebih banyak dipengaruhi oleh fitoplankton, sedangkan cokelat dipengaruhi oleh koloid tanah akibat penambangan pasir pada perairan yang baru.

Pada umumnya oksigen terlarut $\geq 4 \mathrm{mg} / \mathrm{L}$, $\mathrm{CO}_{2} \leq 6 \mathrm{mg} / \mathrm{L}$ dan pH 7-7,5 (Gambar 2-5). Bila dibandingkan dengan kriteria kualitas air yang dinyatakan oleh Boyd (1982) maka kandungan $\mathrm{O}_{2}, \mathrm{CO}_{2}$ dan $\mathrm{pH}$ di perairan bekas galian pasir cukup baik untuk mendukung kehidupan ikan perairan umum. Oksigen terlarut pada umumnya mengalami penurunan dengan bertambahnya kedalaman walaupun pada beberapa perairan di antaranya Sukadami, Sukasari, Cihuni dan Cisauk ditemukan kenaikan $\mathrm{O}_{2}$ terlarut di lapisan bawah permukaan. Hal ini menunjukkan bahwa terjadi peningkatan fotosintesis oleh fitoplankton yang menghasilkan oksigen. Schmittou (1991) menyatakan bahwa oksigen terlarut di perairan sebagian besar $(90 \%)$ dihasilkan dari proses fotosintesis. Oksigen terlarut di perairan bekas galian pasir berkisar antara 1,1 dan $9,0 \mathrm{mg} / \mathrm{L}$, nilai $\mathrm{O}_{2}$ sebesar $1,1 \mathrm{mg} / \mathrm{L}$ tercatat di daerah dasar perairan $(6 \mathrm{~m})$. Oksigen terlarut yang cukup tinggi akan menetralisir racun seperti $\mathrm{N}-\mathrm{NH}_{3}$, $\mathrm{H}_{2} \mathrm{~S}$ menjadi senyawa $\mathrm{N}$ dan $\mathrm{S}$ yang tidak beracun dan mendukung kesuburan perairan. Karbon dioksida pada umumnya mengalami peningkatan dengan bertambahnya kedalaman sehingga berbanding terbalik dengan kandungan $\mathrm{O}_{2}$. Rendahnya $\mathrm{CO}_{2}$ di daerah permukaan perairan karena digunakan dalam proses fotosintesis. Konsentrasi $\mathrm{CO}_{2}$ di perairan berkisar antara 0 dan $12 \mathrm{mg} / \mathrm{L}$.

Keasaman berkisar antara 7 dan 8, yang tersebut berada pada kisaran optimum bagi kehidupan ikan dan organisme perairan lainnya. Seperti yang dikemukakan oleh NTAC (1968), pH perairan yang ideal bagi kehidupan ikan adalah $6,5-8,5$. Pada umumnya $\mathrm{pH}$ di daerah permukaan lebih besar dibandingkan di daerah dasar. Suhu udara berkisar antara $32-35^{\circ} \mathrm{C}$ dan suhu air pada seluruh lapisan air berkisar antara $29-34^{\circ} \mathrm{C}$. Suhu air mengalami penurunan dengan semakin bertambahnya kedalaman. Penurunan suhu air tidak terlalu tajam sehingga tidak terlihat adanya stratifikasi suhu air.

Total alkalinitas berkisar antara 13 dan 80 $\mathrm{mgCaCO} / \mathrm{L}$ dan secara distribusi vertikal tidak menunjukkan pola yang tetap seperti halnya $\mathrm{O}_{2}$, $\mathrm{CO}_{2}, \mathrm{pH}$ dan suhu air (Gambar 2-5). Menurut Swingle (1968) perairan dengan total alkalinitas 10 dan $50 \mathrm{mgCaCO}_{3} / \mathrm{L}$ termasuk perairan dengan tingkat alkalinitas rendah. Berdasarkan klasifikasi tersebut maka perairan bekas galian pasir termasuk perairan dengan alkalinitas sedang, yang berarti cukup produktif untuk mendukung kesuburan perairan.

Kecerahan berkisar antara 35 dan $200 \mathrm{~cm}$ (Lampiran 1), nilai kecerahan yang tinggi umumnya ditemukan di perairan yang sudah relatif stabil artinya air sudah tidak disedot digunakan untuk mencampur pasir seperti di Sukasari dan Cihuni. Hal ini menandakan bahwa di kedua perairan tersebut airnya jernih dibandingkan perairan lainnya. Cahaya matahari akan menembus kedalaman perairan yang jernih sehingga proses fotosintesis vegetasi bentik berlangsung dengan demikian oksigen terlarut cukup tersedia.

Daya Hantar Listrik (DHL) berkisar antara 5-256 $\mu \mathrm{mhos} / \mathrm{cm}$ (Lampiran 1). DHL berhubungan erat dengan kandungan unsur-unsur yang terionisasi. Batas toleransi ikan terhadap DHL dipengaruhi oleh kesadahan perairan itu. Ikan dapat mentolerir DHL berkisar antara $>25-<500$ $\mu$ mhos $/ \mathrm{cm}$ (Boyd, 1982). Total Padatan Terlarut (TPT) berkisar antara 58-488 mg/L (Lampiran 1). Ikan dapat hidup dengan baik bila total padatan terlarut di perairan kurang dari $500 \mathrm{mg} / \mathrm{L}$.

BOD- $_{5 \text { hari }}$ berkisar antara 0,2 dan $4,3 \mathrm{mg} / \mathrm{L}$ (Lampiran 1). Bila dibandingkan dengan kriteria menurut Hynes (1974) maka perairan bekas galian termasuk dalam perairan yang bersih sampai kotor.

Nitrogen diukur dalam bentuk N-NO, $\mathrm{N}_{3}-\mathrm{NH}_{4}$, $\mathrm{N}-\mathrm{NO}_{2}$ dan $\mathrm{N}-\mathrm{NH}_{3} \cdot \mathrm{N}-\mathrm{NO}_{3}$ berkisar antara 0 dan $4,1 \mathrm{mg} / \mathrm{L}, \mathrm{N}-\mathrm{NH}_{4}$ berkisar antara 0 dan $4,8 \mathrm{mg} / \mathrm{L}$, $\mathrm{N}-\mathrm{NO}_{2}$ berkisar antara 0 dan $1,2 \mathrm{mg} / \mathrm{L}$ dan $\mathrm{N}-\mathrm{NH}_{3}$ berkisar antara 0 dan $4,6 \mathrm{mg} / \mathrm{L}$. Keempat 
kandungan $\mathrm{N}$ ini sangat bervariasi. Penimbunan bahan organik (tumbuhan dan hewan) merupa-
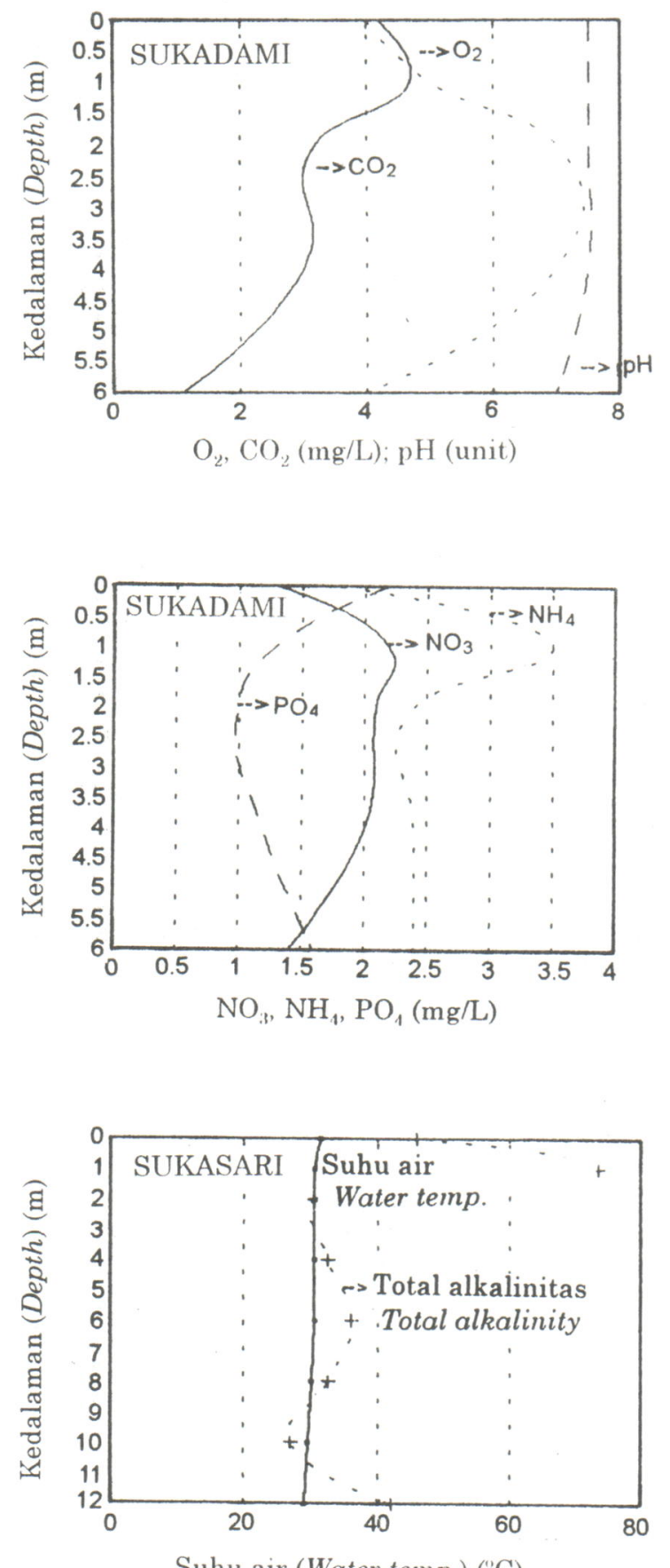

Total alkalinitas (Total alkalinity) ( $\mathrm{mg} / \mathrm{L} \mathrm{CaCO}_{3}$ equ.) kan salah satu penyebab tingginya $\mathrm{N}$ di perairan $\mathrm{N}-\mathrm{NO}_{3}$ dan $\mathrm{N}-\mathrm{NH}_{4}$ merupakan sumber nitrogen

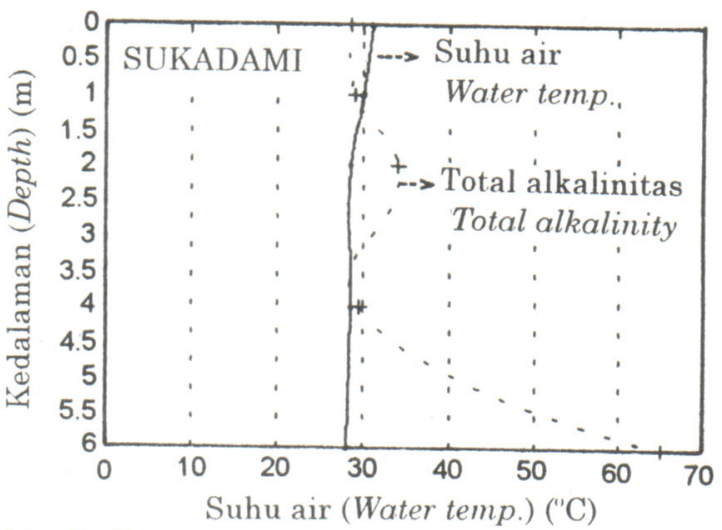

Total alkalinitas (Total alkalinity) (mg/L $\mathrm{CaCO}_{3}$ equ.)
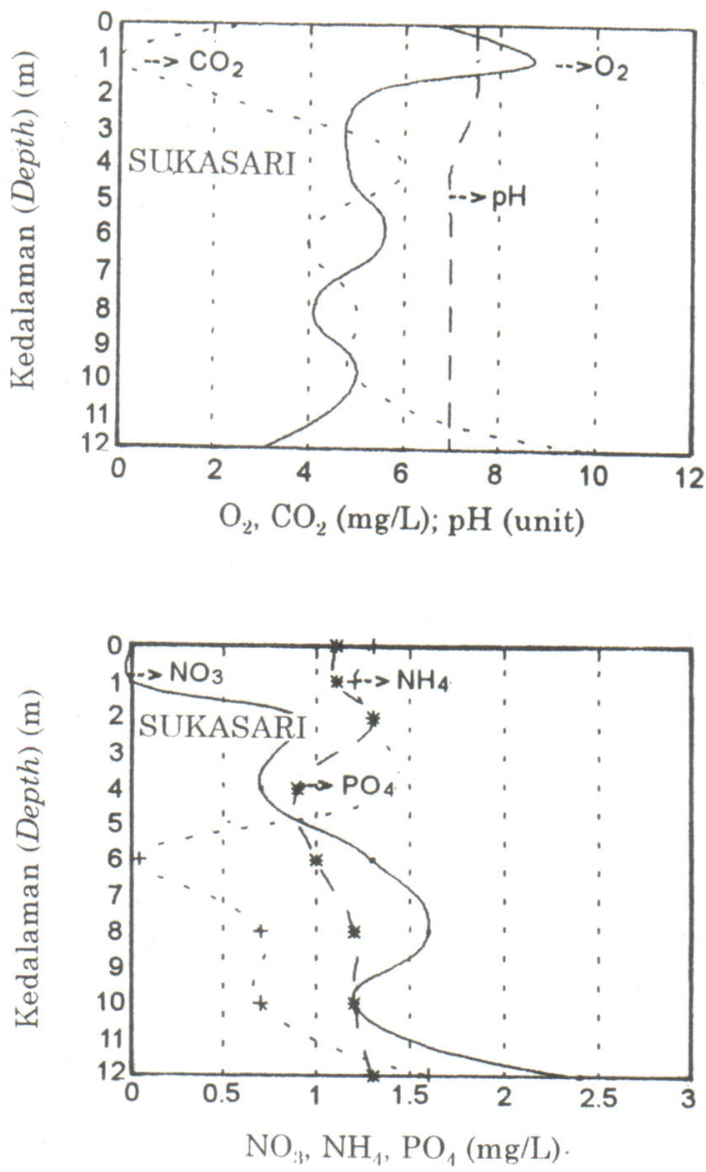

Gambar 2. Parameter oksigen, karbondioksida, $\mathrm{pH}$, suhu air, total alkalinitas, nitrat, amonium, dan fosfat di perairan kolong bekas galian pasir Sukadami dan Sukasari.

Figure 2. Dissolved oxygen, carbon dioxide, $\mathrm{pH}$, water temperature, total alkalinity, nitrate, ammonium, and phosphate of sand mining pools in Sukadami and Sukasari. 

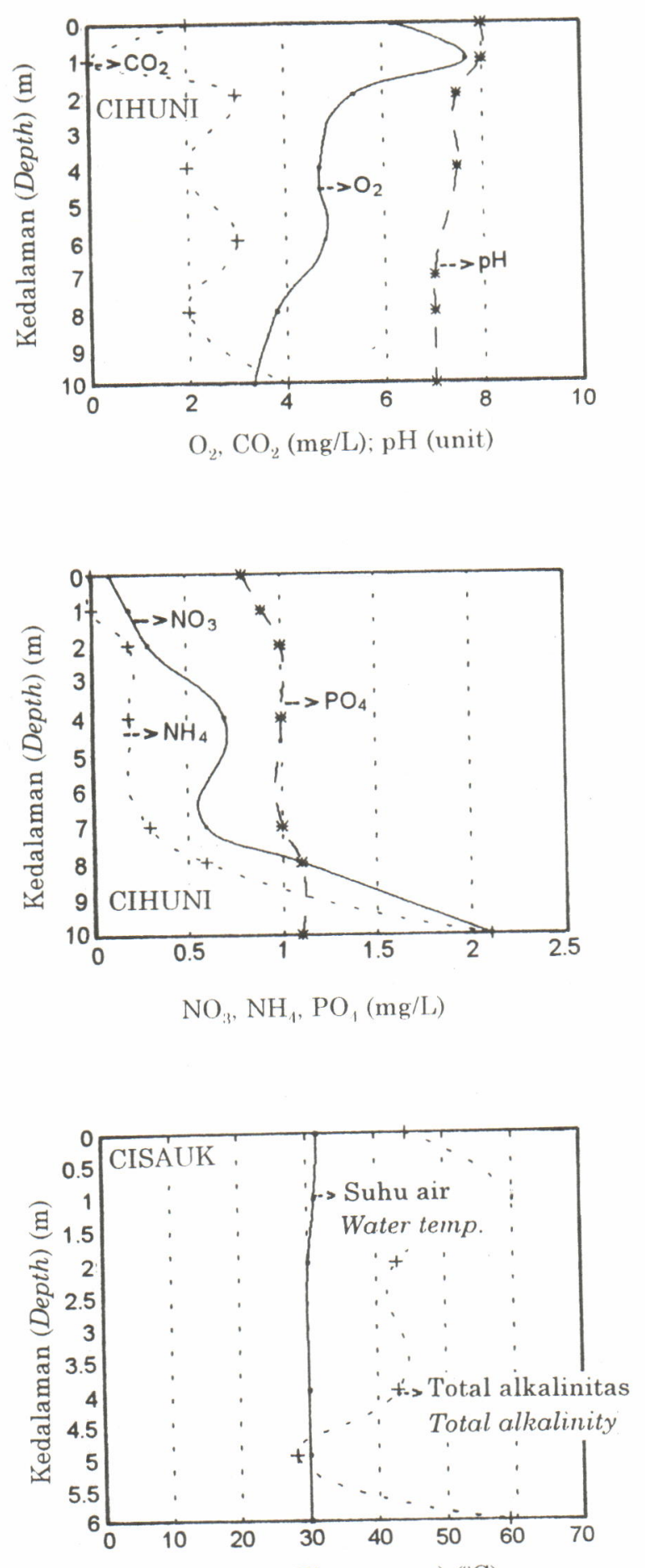

Suhu air (Water temp.) ("C)

Total alkalinitas (Total alkalinity) $(\mathrm{mg} / \mathrm{L} \mathrm{CaCO}, 3$ eqv.)

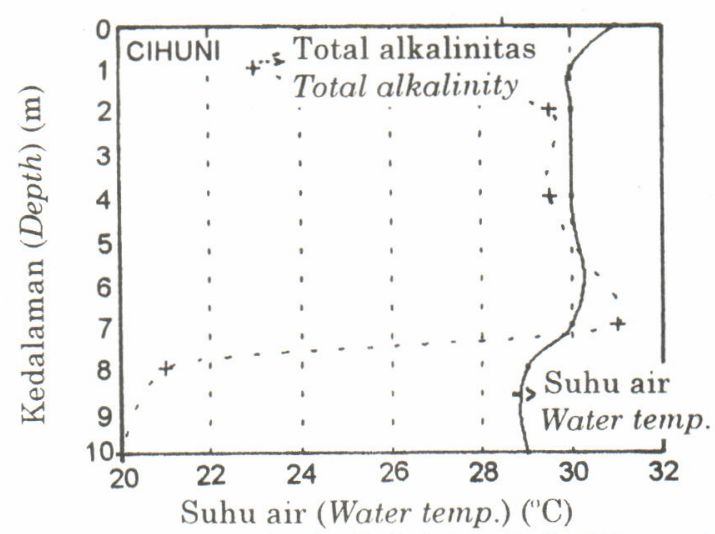

Total alkalinitas (Total alkalinity) $\left(\mathrm{mg} / \mathrm{L} \mathrm{CaCO}_{3}\right.$ eqv.)
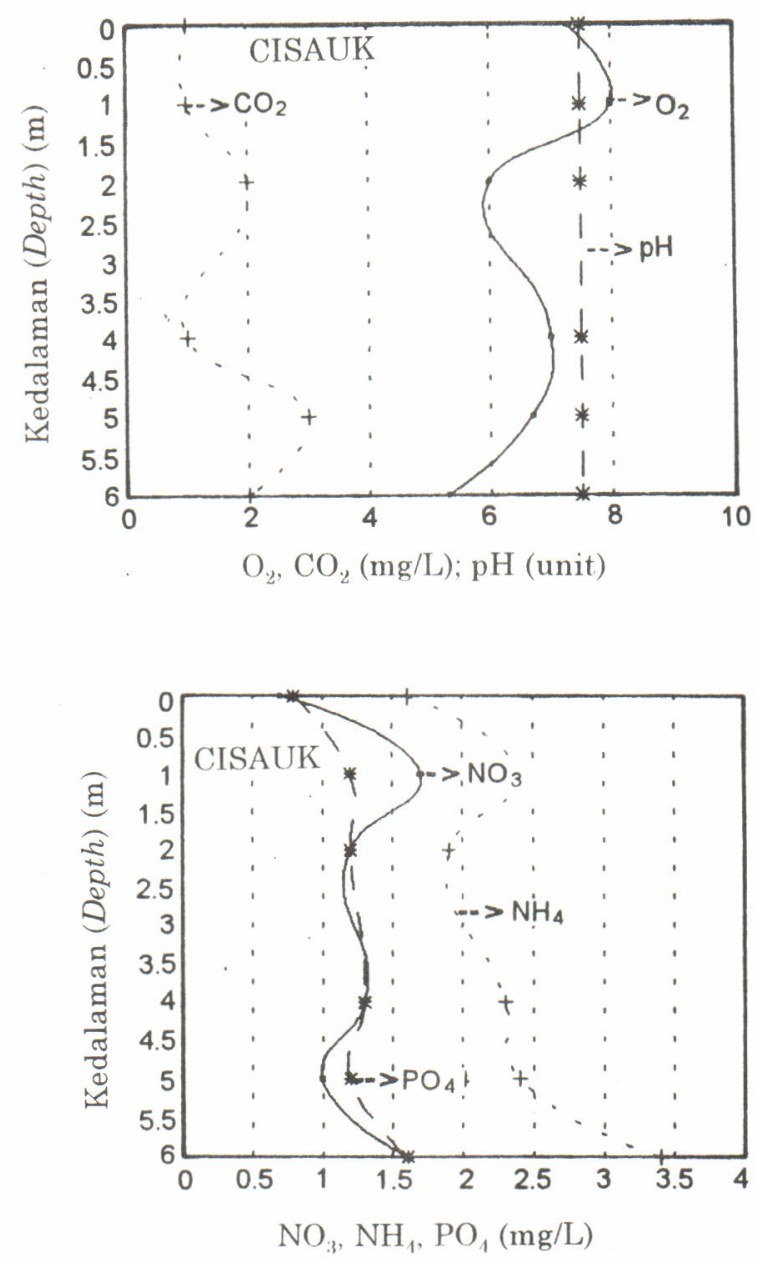

Gambar 3. Parameter oksigen, karbondioksida, pH, suhu air, total alkalinitas, nitrat, amonium, dan fosfat di perairan kolong bekas galian pasir Cihuni dan Cisauk

Figure 3. Dissolved oxygen, carbon dioxide, pH, water temperature, total alkalinity, nitrate, ammonium, and phosphate of sand mining pools in Cihuni and Cisauk. 

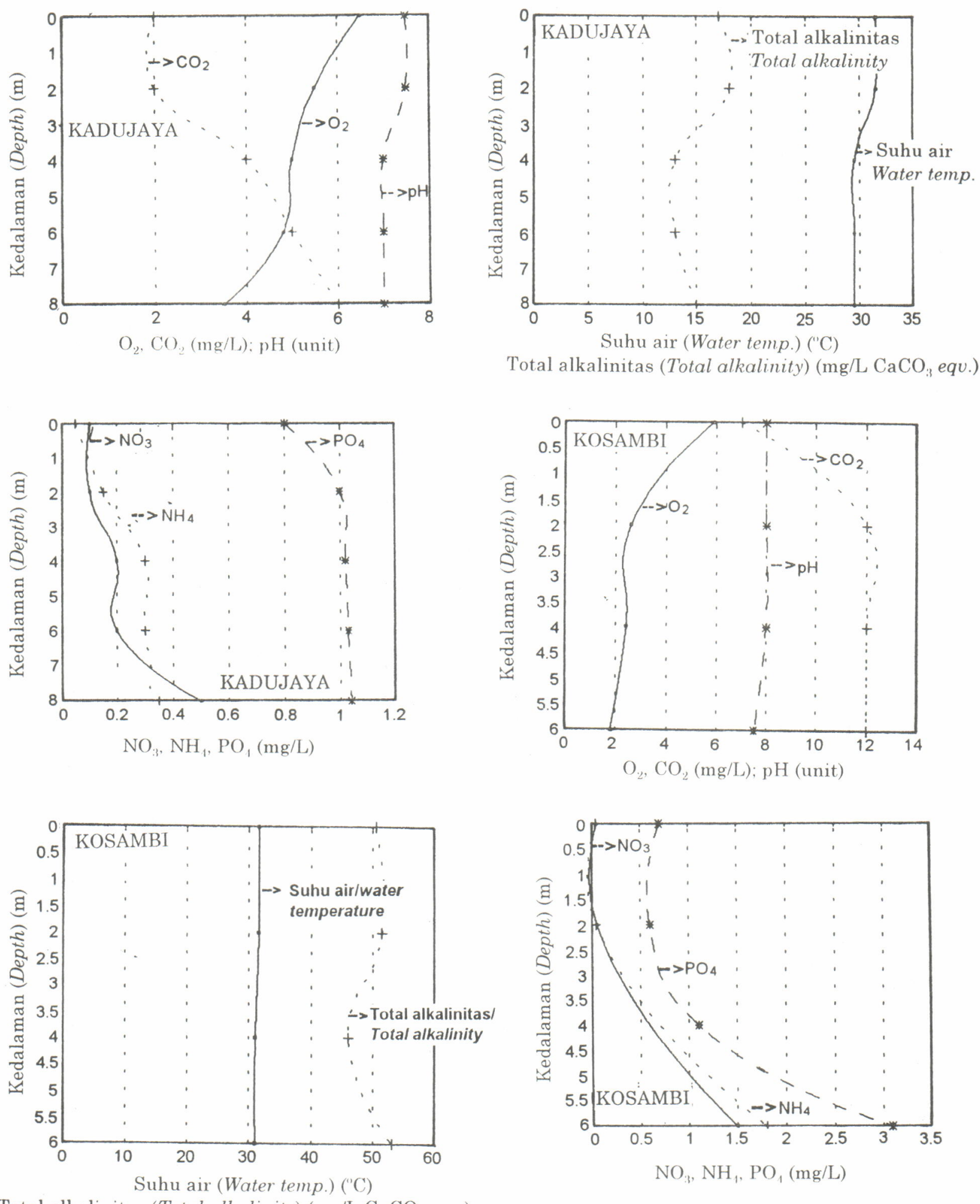

Total alkalinitas (Total alkalinity) (mg/L CaCO, eqv.)

Gambar 4. Parameter oksigen, karbondioksida, $\mathrm{pH}$, suhu air, total alkalinitas, nitrat, amonium, dan fosfat di perairan kolong bekas galian pasir Kadujaya dan Kosambi

Figure 4. Dissolved oxygen, carbon dioxide, pH, water temperature, total alkalinity, nitrate, ammonium, and phosphate of sand mining pools in Kadujaya and Kosambi. 

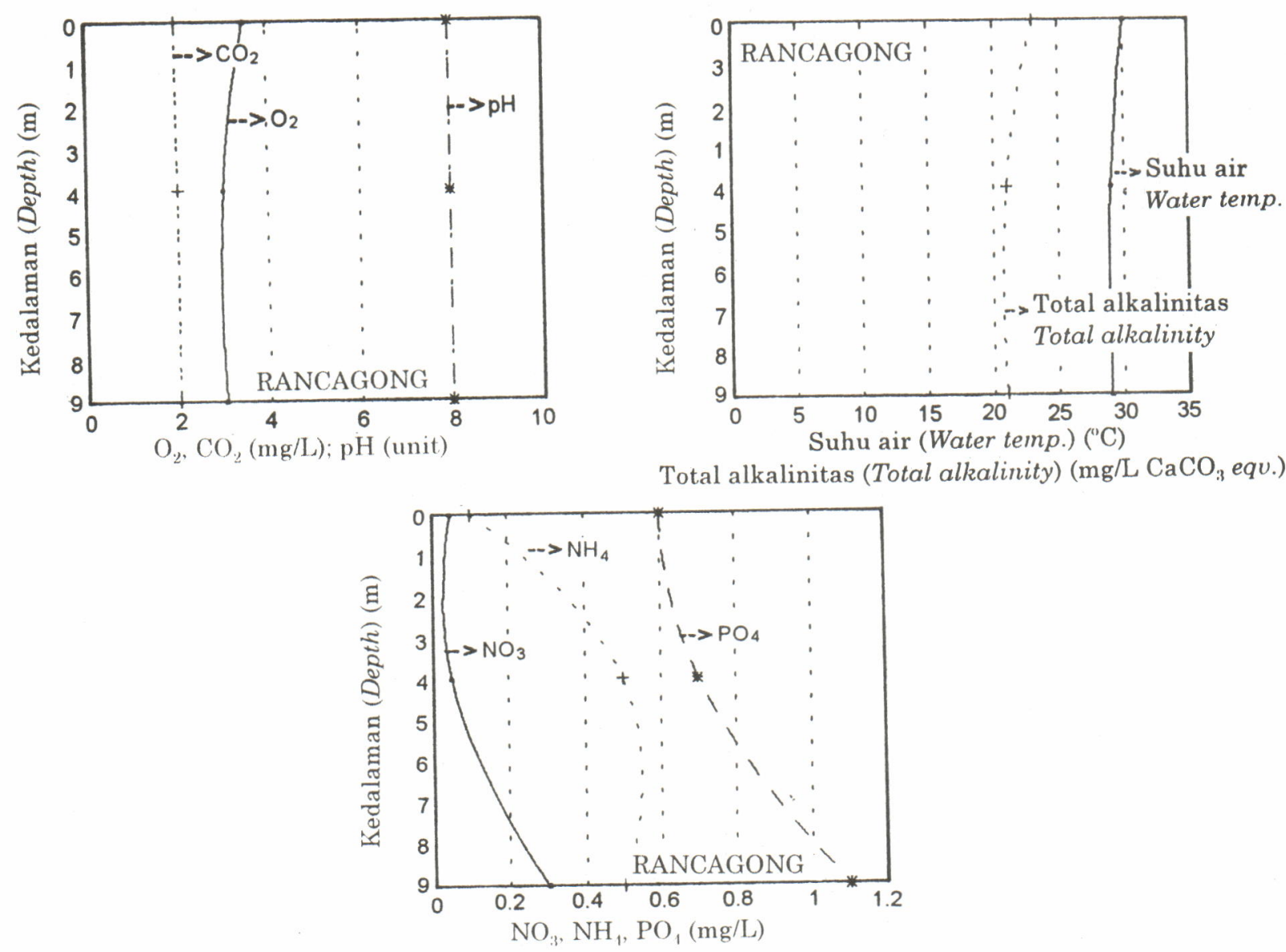

Gambar 5. Parameter oksigen, karbondioksida, $\mathrm{pH}$, suhu air, total alkalinitas, nitrat, amonium, dan fosfat di perairan kolong bekas galian pasir Rancagong.

Figure 5. Dissolved oxygen, carbon dioxide, $\mathrm{pH}$, water temperature, total alkalinity, nitrate, ammonium, and phosphate of sand mining pools in Rancagong.

di perairan sebagai unsur-unsur penting yang dapat digunakan oleh tumbuhan hijau terutama alga serta produsen primer lainnya sehingga kedua bentuk $\mathrm{N}$ ini merupakan salah satu faktor yang menentukan kesuburan perairan. $\mathrm{N}-\mathrm{NH}_{3}$ merupakan hasil utama penguraian protein. Dalam keadaan aerob dengan bantuan bakteri, $\mathrm{N}-\mathrm{NH}_{3}$ dapat diubah menjadi senyawa $\mathrm{N}-\mathrm{NO}_{2}$ dan $\mathrm{N}-\mathrm{NO}_{3}$. Kandungan $\mathrm{N}-\mathrm{NH}_{3}$ yang tinggi di perairan dapat menyebabkan kematian ikan dan organisme akuatik lainnya. Oleh karena itu untuk perikanan $\mathrm{N}-\mathrm{NH}_{3}$ di perairan tidak boleh lebih dari $1,5 \mathrm{mg} / \mathrm{L}$ (Sylvester, 1958) dan di daerah tropis tidak boleh lebih dari $1 \mathrm{mg} / \mathrm{L}$ (Pescod, 1973). Total P di perairan ini berkisar antara 0,2 dan 3,9 mg/L (Lampiran 1), sedangkan nutrien yang dapat diserap oleh organisme nabati adalah dalam bentuk $\mathrm{P}-\mathrm{PO}_{4}$, yang kadarnya dalam perairan diamati berkisar antara 0 dan 2,9 mg/L. Pada Gambar 2-5 ditunjukkan distribusi vertikal $\mathrm{N}-\mathrm{NO}_{3}, \mathrm{~N}-\mathrm{NH}_{4}$ dan $\mathrm{P}-\mathrm{PO}_{4}$, yang umumnya mengalami peningkatan nutrien dengan bertambahnya kedalaman. Menurut klasifikasi kesuburan perairan oleh Ryding \& Rast (1989) maka perairan bekas galian pasir termasuk perairan yang cenderung hipertrofik (sangat subur), dengan demikian di perairan bekas galian pasir dapat dilakukan penebaran ikan yang sesuai dengan makanan yang tersedia untuk pemanfaatan lahan perairan tersebut.

Sulfat $\left(\mathrm{SO}_{4}\right)$ berkisar antara 0,04 dan $4 \mathrm{mg} / \mathrm{L}$ (Lampiran 1). Kandungan sulfat yang tinggi terdapat di perairan daerah Kosambi dan Sukadami. Sumber sulfat di daerah Kosambi diduga berasal dari limbah rumah tangga karena perairannya terletak di tengah-tengah pemukiman dan perairan tersebut digunakan oleh penduduk di sekelilingnya untuk kegiatan rumah tangga. Perairan di Sukadami selain untuk mendukung 
kegiatan rumah tangga juga digunakan sebagai tempat pencucian kendaraan. Umur perairan di daerah Kosambi dan Sukadami lebih tua (> 5 tahun) dibandingkan perairan lainnya yang diamati. Bertambahnya umur seiring dengan peningkatan nutrien. Sulfat di perairan berperanan dalam metabolisme protein bagi pertumbuhan tanaman. Berdasarkan keadaan perairan di Kosambi dan Sukadami maka sangat kecil kemungkinan dikembangkanya kegiatan budidaya ikan.

Kalsium (Ca) berkisar antara 4 dan $88 \mathrm{mg} / \mathrm{L}$ (Lampiran 1) yang berarti bahwa perairan termasuk perairan dengan kandungan Ca sedang sampai tinggi. Banyaknya $\mathrm{Ca}$ ini menentukan tersedianya unsur-unsur hara terutama fosfat, karena Ca dapat menyebabkan pengendapan fosfat.

Magnesium (Mg) berkisar antara 10 dan 108 mg/L (Lampiran 1). Mg diperairan sangat erat hubungannya dengan ion $\mathrm{Ca}$ dan menentukan kesadahan perairan. Kesadahan ini dapat memberikan ciri khas terhadap komunitas biota perairan. Kandungan Mg di perairan ini menunjukkan bahwa perairan ini cukup produktif mendukung kesuburan perairan.

Zat organik berkisar antara 4 dan $42 \mathrm{mg} / \mathrm{L}$ (Lampiran 1). Nilai bahan organik yang tinggi disebabkan karena pada perairan baru masih terdapat penumpukan bahan organik dari sisa tanaman atau hewan yang terendam. Zat organik mempunyai peranan penting dalam rantai makanan jasad perairan terutama bagi jasad perairan pemakan detritus. Namun penambahan bahan organik yang berlebihan dapat mencemari perairan dengan menurunnya kecerahan, oksigen terlarut dan meningkatnya $\mathrm{CO}_{2}$. Menurut Stumn \& Morgan (1970) perairan dengan kandungan bahan organik lebih dari $10 \mathrm{mg} / \mathrm{L}$ termasuk perairan yang tercemar.

Timah hitam $(\mathrm{Pb})$ berkisar antara 20 dan 80 $\mu \mathrm{g} / \mathrm{L}$ (Lampiran 1). Menurut Pescod (1973) ikan mampu bertoleransi dengan $\mathrm{Pb}$ di perairan kurang dari $30 \mu \mathrm{g} / \mathrm{L}$.

Timah putih (Sn) terdapat sampai $90 \mu \mathrm{g} / \mathrm{L}$ (Lampiran 1). Air raksa (Hg) berkisar antara 0,009 dan 0,054 $\mu \mathrm{g} / \mathrm{L}$ (Lampiran 1). Menurut Pescod (1973) ikan hanya mampu bertoleransi dengan $\mathrm{Hg}$ kurang dari $20 \mu \mathrm{g} / \mathrm{L}$. Tembaga $(\mathrm{Cu})$ berkisar antara $10 \mathrm{dan} 40 \mu \mathrm{g} / \mathrm{L}$ (Lampiran 1).
Menurut Pescod (1973) ikan hanya mampu bertoleransi dengan $\mathrm{Cu}$ kurang dari $20 \mu \mathrm{g} / \mathrm{L}$. Logam berat seperti $\mathrm{Pb}, \mathrm{Hg}$ dan $\mathrm{Cu}$ bila berlebih di perairan akan terakumulasi di tubuh ikan atau organisme lainnya dan akan menyebabkan rusaknya jaringan syaraf. Lebih berbahaya bila ikan tersebut dimakan oleh manusia maka juga akan terjadi kerusakan jaringan syaraf yang menyebabkan tubuh cacat/tidak normal walaupun akibatnya tidak cepat terlihat.

Besi (Fe) berkisar antara 0 dan $1,9 \mathrm{mg} / \mathrm{L}$ (Lampiran 1). Fe di perairan mempunyai peranan penting dalam metabolisme dan fotosintesis pada organisme. Menurut Sylvester (1958) untuk kehidupan ikan yang baik kandungan Fe di perairan maksimum $0,02 \mathrm{mg} / \mathrm{L}$. Bila dibandingkan dengan hasil pengukuran di perairan terlihat melebihi kriteria yang ditentukan, walaupun tidak pernah menyebabkan kematian ikan, karena ketersediaan kandungan $\mathrm{O}_{2}$ akan terjadi pengikatan $\mathrm{Fe}$ dan $\mathrm{P}_{-} \mathrm{PO}_{4}$ menjadi senyawa di dasar perairan.

Berdasarkan Tabel 2 diketahui bahwa pada umumnya perairan baru bekas galian pasir memiliki mutu air sedang. Konsentrasi oksigen terlarut pada umumnya untuk seluruh perairan dan seluruh musim sesuai dengan kriteria untuk kehidupan ikan yang baik. Konsentrasi N-NH pada umumnya lebih dari kriteria maksimum yang ditentukan, hal ini diduga berasal dari hasil penguraian bahan organik yang tertimbun pada dasar perairan.

\section{Tanah}

Hasil analisis beberapa parameter tanah dapat dilihat pada Lampiran 2. Tekstur pada umumnya adalah pasir dengan warna cokelat pada perairan yang relatif muda umurnya (1 tahun), sedangkan perairan yang sudah tua (lebih dari 5 tahun) adalah pasir berlumpur dan warna tanah hitam.

Keasaman $(\mathrm{pH})$ tanah berkisar antara 4,5 dan 7,8 yang berarti bahwa ketersediaan unsur-unsur hara makro tinggi. Pada umumnya $\mathrm{pH}$ tanah berkisar antara 4 dan 8,5. Nilai pH tanah dasar perairan di Sukadami berkisar 5,9 dan 7,8 termasuk dalam kelompok yang berkoloid oksida berarti bahwa bisa terjadi senyawa dengan ion $\mathrm{Al}$ dan Fe. Tanah dasar di Sukasari pH berkisar antara 5,4 dan 6,5 termasuk dalam kelompok 
koloid liat dan oksida, di Cihuni dengan $\mathrm{pH} 4$ termasuk dalam kelompok koloid organik, di Cisauk pH berkisar antara 5 dan 5,8 termasuk dalam koloid organik dan liat. Keasaman tanah dasar di perairan Kadujaya 5,9 sedangkan di Kosambi berkisar antara 6,4 dan 7,6 termasuk dalam koloid oksida (Soepartini, 1987).

Nitrogen $(\mathrm{N})$ berkisar antara 0,1 dan $0,8 \%$. Carbon (C) berkisar antara 0,07 dan 0,8\%. Rasio $\mathrm{C} / \mathrm{N}$ yang baik untuk tanah berkisar antara 10 dan 12 , bila rasio $\mathrm{C} / \mathrm{N}$ semakin rendah dekom- posisi semakin cepat. Ratio $\mathrm{C} / \mathrm{N}$ tanah dasar perairan bekas galian pasir berkisar antara 5-9:10.

Fosfor (P) berkisar antara 3,9 dan 5,6 mg/100 g. Rasio C/P kurang dari 200:1 terjadi peristiwa mineralisasi sedangkan lebih dari 300:1 terjadi peristiwa imobilisasi. Rasio tanah dasar perairan bekas galian pasir berkisar antara 0,2-1,4:10. Berdasarkan kandungan $\mathrm{N}$ dan $\mathrm{P}$ diketahui bahwa tanah dasar perairan cepat mengalami dekomposisi dan terjadi mineralisasi.

Tabel 2. Penghitungan skor dari status kualitas air.

Table 2. Score measurement of the water quality status.

\begin{tabular}{|c|c|c|c|c|c|c|c|c|c|}
\hline \multirow{2}{*}{$\begin{array}{c}\text { Lokasi } \\
\text { Location }\end{array}$} & \multicolumn{6}{|c|}{ Skor (Score) } & \multirow{2}{*}{$\begin{array}{c}\text { Jumlah } \\
\text { Total }\end{array}$} & \multirow{2}{*}{$\begin{array}{l}\text { Kelas } \\
\text { Class }\end{array}$} & \multirow{2}{*}{$\begin{array}{l}\text { Status } \\
\text { Status }\end{array}$} \\
\hline & SA TPT & $\mathrm{pH}$ & $\mathrm{O}_{2}$ & $\mathrm{CO}_{2}$ & $\mathrm{~N}-\mathrm{NO}_{2}$ & $\mathrm{~N}-\mathrm{NH}_{3}$ & & & \\
\hline
\end{tabular}

Sukadami:

July ' 95

Sept. ' 95

Nov. '95

Jan. '96

Feb. ' 96

Sukasari:

July ' 95

Sept. ' 95

Nov. '95

Jan. '96

Feb. ' 96

$\begin{array}{ll}0 & 0 \\ 0 & -1 \\ 0 & -1 \\ 0 & 0 \\ 0 & 0\end{array}$

$\begin{array}{cc}0 & -10 \\ 0 & 0 \\ 0 & 0 \\ 0 & -10 \\ 0 & -4\end{array}$

-10
-10
-10
-10
-8

$-8$

$-10$

$-10$

$-8$

0

\section{$-10$}

$$
-10
$$

$-8$

$-10$

$-10$

$-10$

$-8$

$-8$

$-8$

$$
-10
$$

$-10$

$-10$

$-8$

$-8$

Feb. ' 96

Cisauk:

Sept. '95

Nov. '95

Jan. '96

Kadujaya:

July ' 95

Jan. '96

Kosambi:

July '95

Rancagong:

Feb. ' 96

$\begin{array}{ccc}0 & 0 & 0 \\ 0 & 0 & 0 \\ -1 & 0 & 0\end{array}$

0
0
0

$\begin{array}{ccc}0 & -20 \\ -2 & -10 & -8\end{array}$

$\begin{array}{cc}-20 & -20 \\ -8 & -10 \\ -10 & 0\end{array}$

$-28$

$-21$

$-21$

$-28$

$-12$

$-29$

$-20$

$-19$

$-19$

$-27$

$-20$

$-15$

$-26$

$-26$

$-40$

$-18$

$-13$

$-12$

$-20$

$-30$

C sedang (fair)

C sedang (fair)

$\mathrm{SA}=$ Suhu Air (Water temperature),TPT=Total Padatan Terlarut (Total Dissolved Solid) 


\section{Biologi}

Plankton yang ditemukan di perairan bekas bahan galian pasir dapat dilihat pada Lampiran 3-7. Beberapa plankton yang ditemukan adalah dari kelompok Cyanophyta, Chlorophyta, Chryso- phyta, Protozoa, Rotifera, Copepoda dan Cladocera. Kelompok plankton yang sering ditemukan adalah Chlorophyta. Namun keragaman plankton sangat rendah yaitu berkisar antara 0 dan 0,193 (Tabel 3).

Tabel 3. Indeks diversitas plankton di perairan kolong bekas galian pasir.

Table 3. Diversity Index of plankton in sand mining pools

\begin{tabular}{|c|c|c|c|c|c|c|}
\hline \multirow{2}{*}{\multicolumn{2}{|c|}{$\begin{array}{c}\text { Lokasi/kedalaman } \\
\text { Location/depth } \\
\text { (m) }\end{array}$}} & \multicolumn{5}{|c|}{ Indeks diversitas, pada bulan; (Diversity index, on month:) } \\
\hline & & \multirow{2}{*}{$\frac{\text { July '95 }}{0}$} & \multirow{2}{*}{$\frac{\text { Sept. '95 }}{0.125}$} & \multirow{2}{*}{$\begin{array}{c}\text { Nov. '95 } \\
0.100\end{array}$} & \multirow{2}{*}{$\frac{\text { Jan. '96 }}{0.154}$} & \multirow{2}{*}{$\begin{array}{c}\text { Feb. '96 } \\
0.154\end{array}$} \\
\hline Sukadami: & 0 & & & & & \\
\hline & 1 & - & 0.135 & 0.095 & - & \\
\hline & 2 & 0.107 & 0.151 & - & 0.142 & 0.153 \\
\hline & 4 & 0.156 & 0.134 & - & 0.148 & 0.153 \\
\hline & 6 & 0.157 & 0.153 & - & - & - \\
\hline \multirow[t]{8}{*}{ Sukasari: } & 0 & - & 0.084 & 0.143 & 0.159 & 0.155 \\
\hline & 1 & - & 0.045 & & - & \\
\hline & 2 & - & - & 0.074 & 0.142 & 0.150 \\
\hline & 4 & & - & 0.135 & 0.097 & 0.138 \\
\hline & 7 & - & - & 0.124 & - & - \\
\hline & 8 & - & - & 0.132 & 0.118 & 0.089 \\
\hline & 10 & - & - & - & 0.140 & - \\
\hline & 12 & - & - & - & - & 0.185 \\
\hline \multirow[t]{8}{*}{ Cihuni: } & 0 & - & 0.159 & 0.099 & 0.089 & 0.142 \\
\hline & 1 & - & 0.082 & - & - & - \\
\hline & 2 & - & 0.159 & 0.137 & 0.158 & 0.153 \\
\hline & 4 & - & 0.122 & 0.042 & 0.150 & 0.148 \\
\hline & 7 & - & - & 0.068 & - & 0 \\
\hline & 8 & - & - & - & - & 0.097 \\
\hline & 10 & - & - & - & 0.150 & - \\
\hline & 12 & & $\therefore$ & - & - & 0.142 \\
\hline \multirow[t]{5}{*}{ Cisauk: } & 0 & - & 0.155 & 0.177 & 0.138 & - \\
\hline & 1 & - & 0.115 & - & - & - \\
\hline & 2 & - & 0.087 & 0.143 & 0.142 & - \\
\hline & 4 & - & 0.193 & 0.129 & - & - \\
\hline & 5 & & 0.105 & - & 0.124 & - \\
\hline \multirow[t]{4}{*}{ Kadujaya: } & 0 & 0.131 & - & - & 0.156 & - \\
\hline & 2 & 0.159 & - & - & 0.124 & - \\
\hline & 4 & - & & - & 0.125 & - \\
\hline & 6 & & - & - & 0.159 & - \\
\hline \multirow[t]{4}{*}{ Kosambi: } & 0 & 0.111 & - & & - & - \\
\hline & 1 & - & - & - & - & \\
\hline & 2 & 0.108 & - & & - & $\cdot$ \\
\hline & $\begin{array}{l}4 \\
6\end{array}$ & $\begin{array}{l}0.075 \\
0.078\end{array}$ & - & - & - & - \\
\hline \multirow{3}{*}{ Rancagong: } & 0 & - & - & & . & 0.139 \\
\hline & 4 & - & . & . & 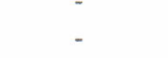 & $\begin{array}{l}0.139 \\
0.159\end{array}$ \\
\hline & 9 & - & - & - & - & 0.159 \\
\hline
\end{tabular}


Keragaman plankton yang sangat rendah menunjukkan bahwa perairan kurang stabil Beberapa hal yang diduga menyebabkan rendahnya keragaman plankton di antaranya adalah umur perairan yang relatif muda dan rasio N/P yang rendah yaitu kurang dari $6: 1$. Rasio $\mathrm{N}: \mathrm{P}$ di perairan umum adalah $15: 1$ (Porcella \& Bishop 1975).

Bentos (organisme dasar) yang ditemukan adalah dari kelompok Moluska (Bithynia, Campeloma, Corbicula, Lymnaea, Marisa, Nassa, Poinacea, Pteurocera dan Tarebia), Krustasea (Mysis), Diptera (Chironomus dan Tabanus) serta Nemathelmintes (Diplogasteroides dan Monhystera). Sedangkan yang paling sering ditemukan adalah dari kelompok Moluska. Keragaman benthos di perairan baru bekas galian pasir sangat kecil yaitu dengan nilai indeks diversitas kurang dari 1 (Tabel 4). Bentos ini merupakan cadangan pakan bagi ikan yang hidup di dasar perairan.

Perifiton merupakan alga penempel dan pada umumnya merupakan sumber energi autochtonous di suatu perairan. Di wilayah litoral danau, perifiton dapat berperan sebagai produser primer bahkan dapat mencapai sampai $23 \%$ dari produksi primer total (Szczepansa dalam Lukman \& Widyanto, 1991). Perifiton selain berperan dalam produktivitas primer juga berguna sebagai indikator ekologis dalam menentukan tingkat pen- cemaran (Hill \& Webster, 1982). Di perairan baru ini perifiton menempel baik pada batu,kayu ataupun tanaman air. Beberapa jenis alga yang ditemukan dari kelompok Chlorophyta di antaranya adalah: Tribonema dan Desmidium. Perifiton merupakan sumber makanan invertebrata bentik seperti Moluska, Ephemeroptera, Plecoptera dan limpet air tawar serta makanan utama beberapa jenis ikan (Moss, 1980; Hickling, 1961).

Tanaman air umumnya ditemukan pada perairan yang relatif tua umurnya ( $>5$ tahun) dan hal ini seiring dengan peningkatan nutrien. Tanaman air di perairan ini terlihat tumbuh di tepi perairan sebagai daerah asuhan anak-anak ikan dan sebagai tempat menempelnya telur ikan. Menurut Sterba (1963) telur-telur ikan pelangi (Melanotaenia boesemani) umumnya dijumpai di antara dedaunan tanaman air atau benda-benda seperti serabut di perairan yang dangkal. Hasil penelitian Gunawan (1991) menunjukkan bahwa telur-telur ikan pelangi menempel pada akar eceng gondok (Eichhornia crassipes). Di perairan Sukadami (Bekasi) dan Kosambi (Tangerang) tanaman air ini sudah tumbuh dengan pesat sehingga hampir menutup $30 \%$ perairan. Hal ini akan menghambat tumbuhnya fitoplankton sebagai cadangan pakan alami ikan. Selain hal tersebut pesatnya tanaman air akan mempercepat pendangkalan perairan. Beberapa jenis tanaman air yang ditemukan dapat dilihat pada Tabel 5 .

Tabel 4. Indeks diversitas bentos di perairan kolong bekas galian pasir

Table 4. Index diversity of benthos in sand mining pools.

\begin{tabular}{|c|c|c|c|c|c|}
\hline \multirow{2}{*}{$\begin{array}{l}\text { Lokasi/kedalaman } \\
\text { Location/depth } \\
\text { (m) }\end{array}$} & \multicolumn{5}{|c|}{$\begin{array}{l}\text { Indeks diversitas, pada bulan: } \\
\text { Diversity index, on month: }\end{array}$} \\
\hline & July '95 & Sept. '95 & Nov. '95 & Jan. '96 & Feb. '96 \\
\hline \multicolumn{6}{|l|}{ Bekasi: } \\
\hline Sukasari & 0.159 & 0.077 & 0.116 & - & 0.001 \\
\hline Sukadami & 0.158 & 0.035 & 0.042 & 0.008 & 0.001 \\
\hline \multicolumn{6}{|l|}{ Tangerang: } \\
\hline Cihuni & - & - & - & 0.001 & - \\
\hline Cisauk & - & - & 0.006 & 0.0005 & - \\
\hline Kosambi & 0.080 & - & - & - & - \\
\hline Rancagong & - & - & - & - & 0.006 \\
\hline
\end{tabular}


Tabel 5. Tanaman air yang ditemukan di perairan kolong bekas galian pasir.

Table 5. Aquatic weeds in sand mining pools.

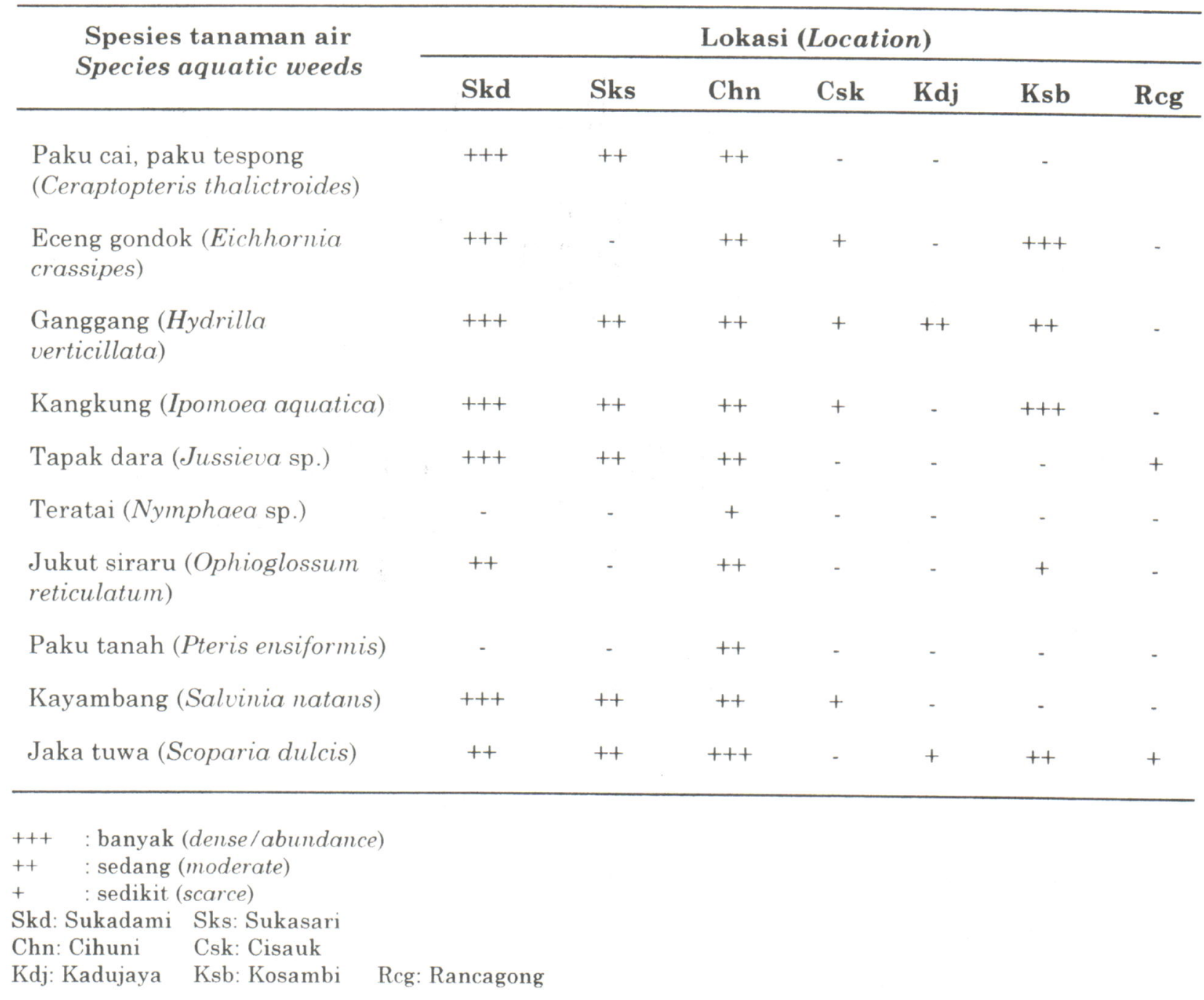

Untuk menentukan kelayakan perairan bagi kegiatan perikanan dilakukan penilaian beberapa faktor yang mendukungnya dapat dilihat pada Tabel 6.

Berdasarkan Tabel 6 diketahui bahwa perairan yang layak untuk kegiatan perikanan adalah Sukasari (Bekasi) dan Cihuni (Tangerang). Kedua perairan tersebut memiliki keunggulan dalam hal relatif stabilnya ketinggian air (kedalaman air) karena air tidak dimanfaatkan untuk penyedotan pasir. Sedangkan di Kosambi walaupun memiliki skor cukup tinggi (12), namun tidak layak untuk kegiatan perikanan karena perairan terletak di tengah pemukiman penduduk dan kegiatan mandi cuci kakus (MCK) penduduk dilakukan di perairan tersebut sehingga diperkirakan akan mempengaruhi higienis ikan.

\section{Status Trofik}

Ditinjau dari stabilitas $\mathrm{O}_{2}$ seperti pada Tabel 7 diketahui bahwa keadaan $\mathrm{O}_{2}$ di perairan bekas galian pasir di Desa Sukasari (Bekasi) dan Cihuni (Tangerang) cukup stabil. Hal ini terlihat dari kandungan $\mathrm{O}_{2}$ di lapisan permukaan yang dinyatakan dengan persentase menunjukkan bahwa besarnya kandungan $\mathrm{O}_{2}$ di permukaan adalah relatif karena sangat dipengaruhi oleh faktor luar seperti atmosfer, goyangan air per- 
mukaan, difusi dari permukaan ke atmosfer bila lewat jenuh (oversaturated) ataupun masuknya material/zat tertentu) dan dasar masih cukup tinggi. Keadaan tersebut menyebabkan kedua perairan diklasifikasikan dalam kelompok oligotrofik. Kandungan nutrien $\left(\mathrm{P}-\mathrm{PO}_{4}\right.$, Total $\mathrm{P}$ dan Total N) pada musim kemarau dan hujan berbeda, walaupun pada kedua musim sudah termasuk dalam klasifikasi yang sama yaitu hipertofik. Kandungan ketiga nutrien pada musim kemarau cenderung lebih tinggi dibandingkan dengan musim hujan. Tingginya nutrien pada musim kemarau diduga disebabkan karena berkurang/surutnya air karena penguapan sehingga konsentrasi nutrien semakin pekat. Sebaliknya proses pengenceran yang terjadi pada musim hujan karena penambahan air menyebabkan rendahnya konsentrasi nutrien.

Tabel 6. Skor untuk menentukan kelayakan perairan kolong bekas galian pasir bagi budidaya ikan. Table 6. Scoring for feasibility of sand mining pools for fish culture.

\begin{tabular}{lccccccc}
\hline \multirow{2}{*}{$\begin{array}{l}\text { Kriteria } \\
\text { Criteria }\end{array}$} & \multicolumn{6}{c}{ Lokasi yang direkomendasikan (Reccomended sites) } \\
\cline { 2 - 7 } & Skd & Sks & Chn & Csk & Kdj & Ksb & Rcg \\
\hline Luas (Area) & 1 & 2 & 2 & 2 & 2 & 1 & 1 \\
Air surut (Low tide) & 3 & 1 & 3 & 1 & 1 & 1 & 1 \\
Mutu air (Water quality) & 2 & 2 & 2 & 2 & 2 & 2 & 2 \\
$\begin{array}{l}\text { Indeks diversitas plankton } \\
\text { (Diversity indexes of plankton) }\end{array}$ & 1 & 1 & 1 & 1 & 1 & 1 & 1 \\
$\begin{array}{l}\text { Indeks diversitas benthos } \\
\text { (Diversity indexes of benthos) }\end{array}$ & 1 & 1 & 1 & 1 & - & 1 & 1 \\
$\begin{array}{l}\text { Kelimpahan tanaman air } \\
\text { (Abundance of aquatic weed) }\end{array}$ & 2 & 3 & 2 & 1 & 1 & 3 & 1 \\
$\begin{array}{l}\text { Penggunaan air untuk } \\
\text { menyedot pasir (Water for sand }\end{array}$ & 3 & 1 & 3 & 1 & 1 & 3 & 1 \\
sucking) & & & & & & & \\
\hline $\begin{array}{l}\text { Jumlah ranking skor (Total } \\
\text { ranking score) }\end{array}$ & 13 & 11 & 14 & 9 & 8 & 12 & 8 \\
\hline
\end{tabular}

$$
\begin{aligned}
& \text { Luas (Area): }<1-3 \text { ha }=1 \text {; } \\
& >3-5 \text { ha }=2 \\
& >5 \text { ha }=3
\end{aligned}
$$

Mutu air (Water quality): buruk (poor): 1 ; sedang (fair): 2 ; bagus (good): 3

Indeks diversitas bentos

Diversity indexes of benthos: $>1$ : 1;

$1-2 \quad: 2$

$<2-3 \quad: 3$

$$
\text { Air surut (Low tide): } \begin{aligned}
1.2 \mathrm{~m} & =3 ; \\
& 2-4 \mathrm{~m}=2 ; \\
>4 \mathrm{~m} & =1
\end{aligned}
$$

Indeks diversitas plankton (Diversity indexes of plankton): $\quad>1$ : 1;

$1-2: 2$;

Kelimpahan tanaman air Abundance of aquatic weed: melimpah (dense): $+++\quad: 3$ cukup (moderate) $:+\quad: 2$ jarang (scarce) : $+\quad$ : 1 
Tabel 7. Status trofik di perairan kolong bekas galian pasir Sukasari (Bekasi) dan Cihuni (Tangerang). Table 7. Trophic status of sand mining pools in Sukasari Bekasi) and Cihuni (Tangerang).

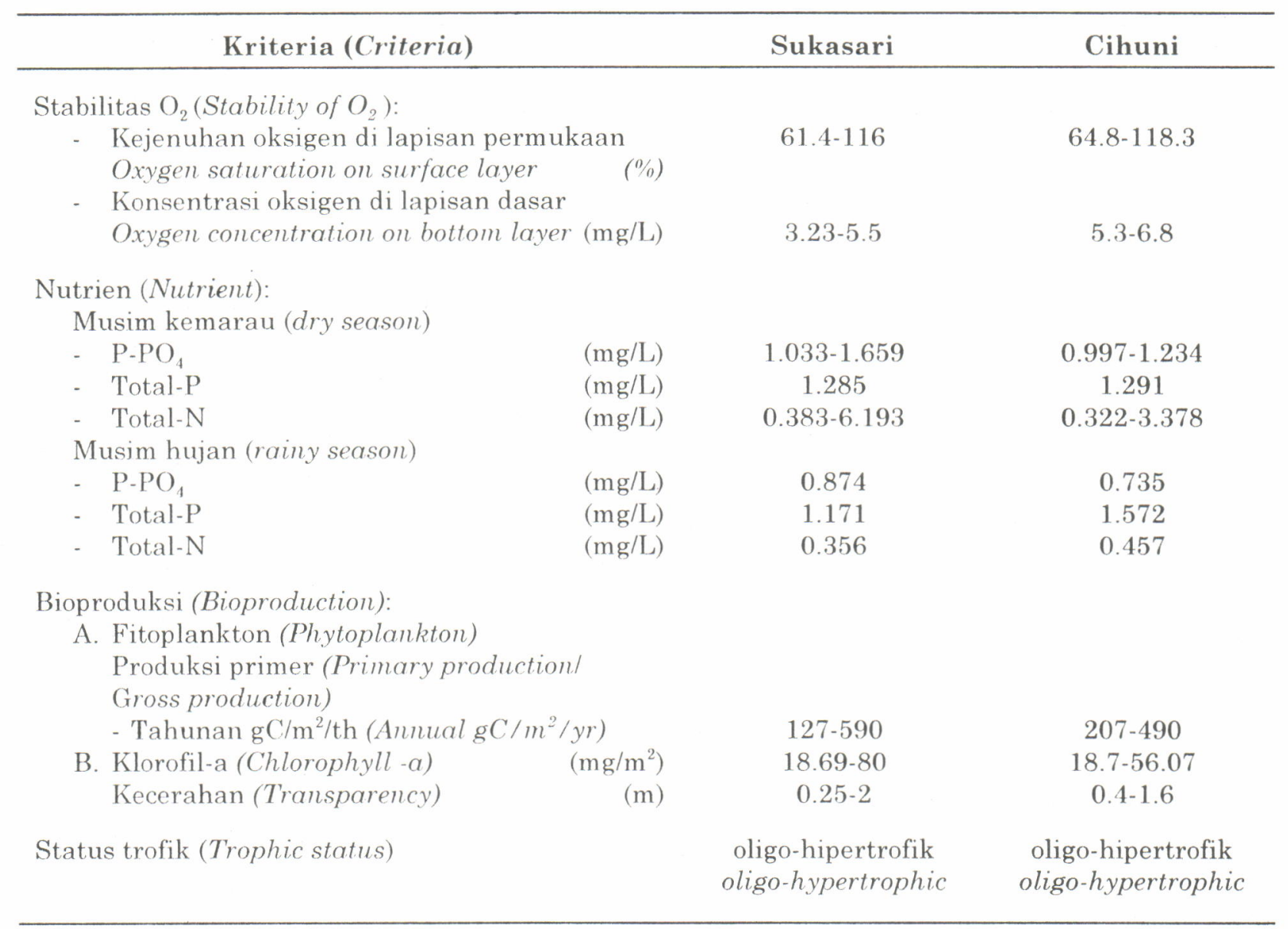

Bila dilihat dari nilai produktivitas primer fitoplankton dan klorofil-a perairan bekas galian pasir di Sukasari dan Cihuni termasuk dalam klasifikasi mesotrofik-hipertrofik. Keadaan hipertrofik dicapai pada satu saat saja untuk Sukasari dicapai pada saat musim kemarau sedangkan untuk Cihuni dicapai pada awal musim hujan, dan pada umumnya keadaan kedua parameter masih dalam klasifikasi mesotrof. Keadaan perairan yang mesotrof yang berarti fitoplankton belum berkembang dapat dilihat dari nilai indeks divesitas kurang dari 1, namun demikian plankton yang tersedia sebagai makanan alami bagi ikan cukup potensial seperti: Chlorella, Brachionus dan Keratella.

Dari hasil pengamatan di kedua perairan bekas galian pasir ditemukan beberapa jenis ikan di antaranya adalah mujair (Oreochromis mossambica), lele (Clarias batrachus), nilem
(Osteochillus haselti), sepat (Trichogaster sp.), tawes (Puntius gonionotus), gabus (Chana striatus), betutu (Oxyeleotris marmorata) dan udang. Berdasarkan uraian di atas maka perairan bekas galian pasir di Sukasari dan Cihuni potensial untuk kegiatan perikanan seperti budidaya atau reservat. Beberapa hal yang mendukung perairan di Sukasari cocok untuk kegiatan budidaya di antaranya adalah kualitas air mendukung kehidupan ikan, luas perairan tidak terlalu luas sehingga mudah dimonitor, air relatif stabil sepanjang tahun dan cukup aman. Ilyas et al. (1989) menegaskan bahwa fluktuasi kedalaman air tahunan yang baik bagi perikanan adalah 2,5-4,0 $\mathrm{m}$ dengan perubahan perlahanlahan. Sistem budidayanya adalah sistem budidaya ikan dalam kolam, ikan yang sesuai dengan keadaan suhu relatif tinggi adalah gurami (Osphronemus gouramy) dengan padat 
tebar 6 ekor $/ \mathrm{m}^{2}$ bobot per ekor 70 gram, sedang pakan adalah pelet terapung yang diberikan $2 \%$ dari bobot ikan (Jangkaru et al., 1993).

\section{KESIMPULAN}

1. Kualitas air di perairan kolong bekas galian pasir yang diamati termasuk klasifikasi mutu $\mathrm{C}$ (sedang) yaitu cukup mendukung kehidupan ikan.

2. Makanan alami (plankton, bentos dan perifiton) tersedia. Indeks keragaman plankton rendah (kurang dari 1). Plankton yang sering ditemukan adalah kelompok Chlorophyceae. Bentos yang sering ditemukan adalah kelompok Moluska dan Perifiton yaitu kelompok Chlorophyceae, di antaranya adalah Tribonema dan Desmidium.

3. Tanaman air sebagai tempat menempelnya telur ikan dan daerah asuhan anak-anak ikan umumnya tumbuh di tepi perairan.

4. Perairan kolong bekas galian pasir (Sukasari dan Cihuni) layak untuk pengembangan perikanan budidaya.

\section{DAFTAR PUSTAKA}

Boyd, C.E. 1982. Water quality management for pond fish culture. Elsevier Scientific Publishing Co. Amsterdam. 318p.

De Silva, S.S. 1988. Reservoirs of Sri Lanka and their fisheries. FAO Fisheries Technical Paper 298. Rome. 128 p

Goldman, C.R and A.J. Horne. 1983. Limnology. Internal Student Edition. McGraw-Hill International Book Company. Paris. 464p.

Gunawan. 1991. Preferensi material penempelan telur dan produksi anakan ikan pelangi (Melanotaenia boesemani). BIO AIR No. 3: 52-55.

Hickling, C.F. 1961. Tropical inland fisheries JohnWiley and Sons Inc., New York, 287pp.

Hill, A.H and J.R. Webster. 1982. Periphyton production in an appalachian river. Hydrobiology (97): 275-280.

Hynes, H.B.N. 1974. The biology of polluted water. Liverpool University. Press. 202p.
Ilyas, S.; E.S. Kartamihardja; F. Cholik; R. Arifudin; Krismono; D.W.H. Tjahjo; Z. Jangkaru; W. Ismail; A. Hardjamulia; E. Pratiwi; H. Supriyadi; Sutrisno; and S. Hadiwigeno. 1989. Petunjuk teknis pengelolaan perairan waduk bagi pembangunan perikanan. Seri Pengembangan Hasil Penelitian Perikanan No.PHP/KAN/07/1989. Badan Litbang Pertanian. Jakarta

Jangkaru, Z; M. Sulhi dan Bambang Gunadi. 1993. Konstruksi tanah dan kedalaman air kolam tadah hujan untuk usaha pemeliharaan ikan gurami. Bull.Penel.Perik.Darat..12(1): 42-43.

Lukman dan T. Widyanto. 1991. Komunitas perifiton pada tumbuhan air (Hydrilla verticillata dan Vallisneria americana) di tiga lokasi danau Sentani. BIO AIR No.3: 37-42

Moss, B. 1980. Ecology of freshwaters. Black Well Scientific Publ. London, 332p.

NTAC. 1973. Water quality criteria, FWPCA., Washington DC,234p.

Pescod, M.B. 1973. Investigation of rational effluent and stream standards for tropical countries, AIT Bangkok, 59p.

Porcella, D.B. and A. B. Bishop. 1975. Comprehensive management of phosphorus water pollution. Ann Arbror Science Publishing Inc.303p.

Ryding, S.O. and W. Rast., 1989. The control of eutrophication of lakes and reservoirs. Man and the biosphere series. Vol 1. The Parthenon Publishing Group. UNESCO. Paris 314p.

Schmittou, H.R. 1991. Cage culture: a method of fish production in Indonesia. FRDP, CRIFI, Jakarta, Indonesia. $114 \mathrm{p}$.

Soepartini, M. 1987. Diktat kimia tanah. Untuk latihan analisa tanah, tanaman, air dan pupuk tanggal 10 Pebruari-13 Maret 1987. Badan Litbang Pertanian Puslittan-P5/NAR II, Bogor.

Sterba, G. 1973. Freshwater fishes of the world. T. F. H. Publication, Inc.Ltd., London.877p.

Stumn, W. and J.J. Morgan. 1970. Aquatic chemistry. Wiley-Interscience. New York.583p.

Swingle, H.S. 1968. Standardization of chemical analyses for water and pond muds. FAO Fish. Rep. 44 (4):397-406.

Sylvester, R.O. 1958. Water quality studies in the Columbia River Basin. U.S. Department Interior. Washington DC. 133p. 


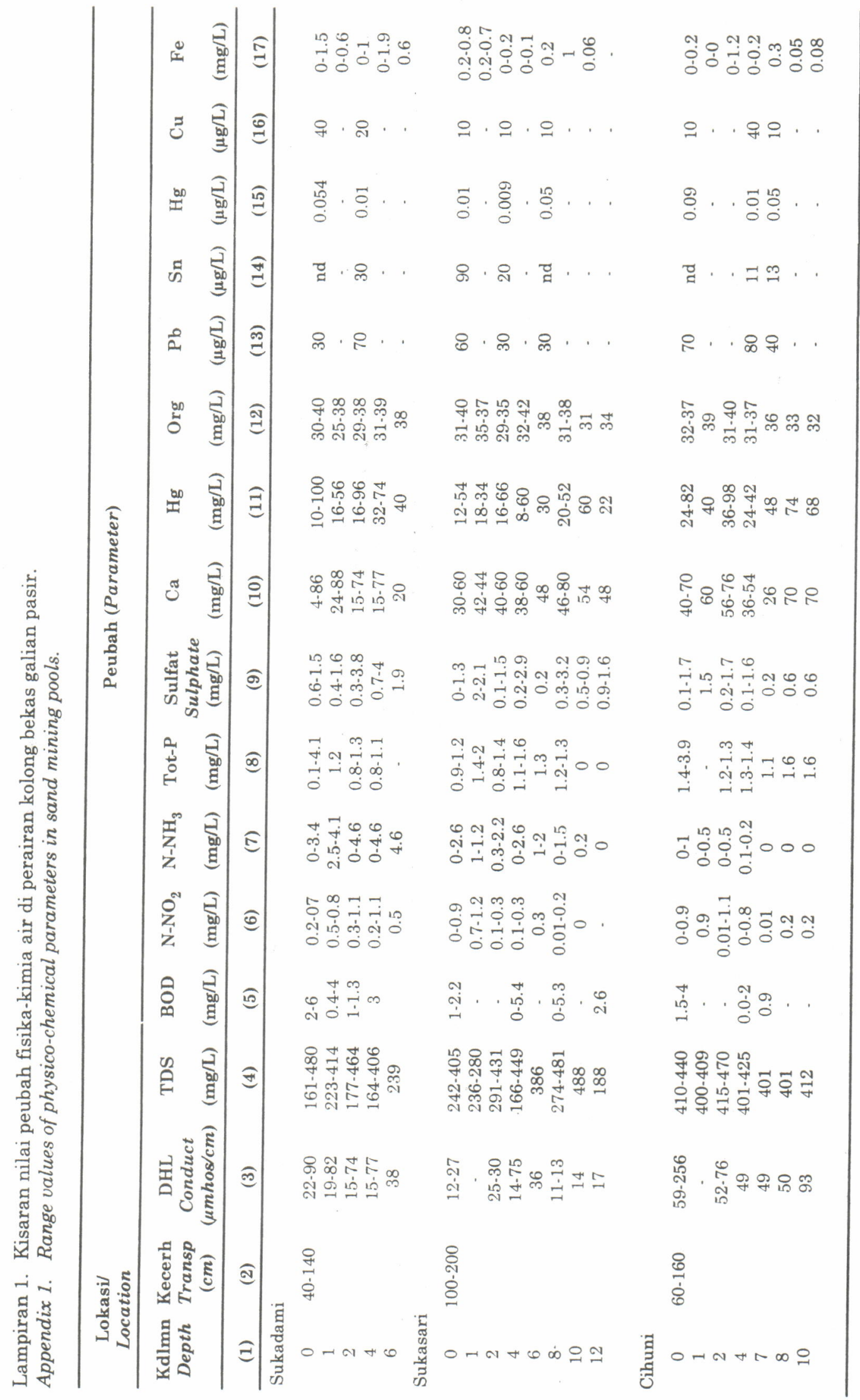




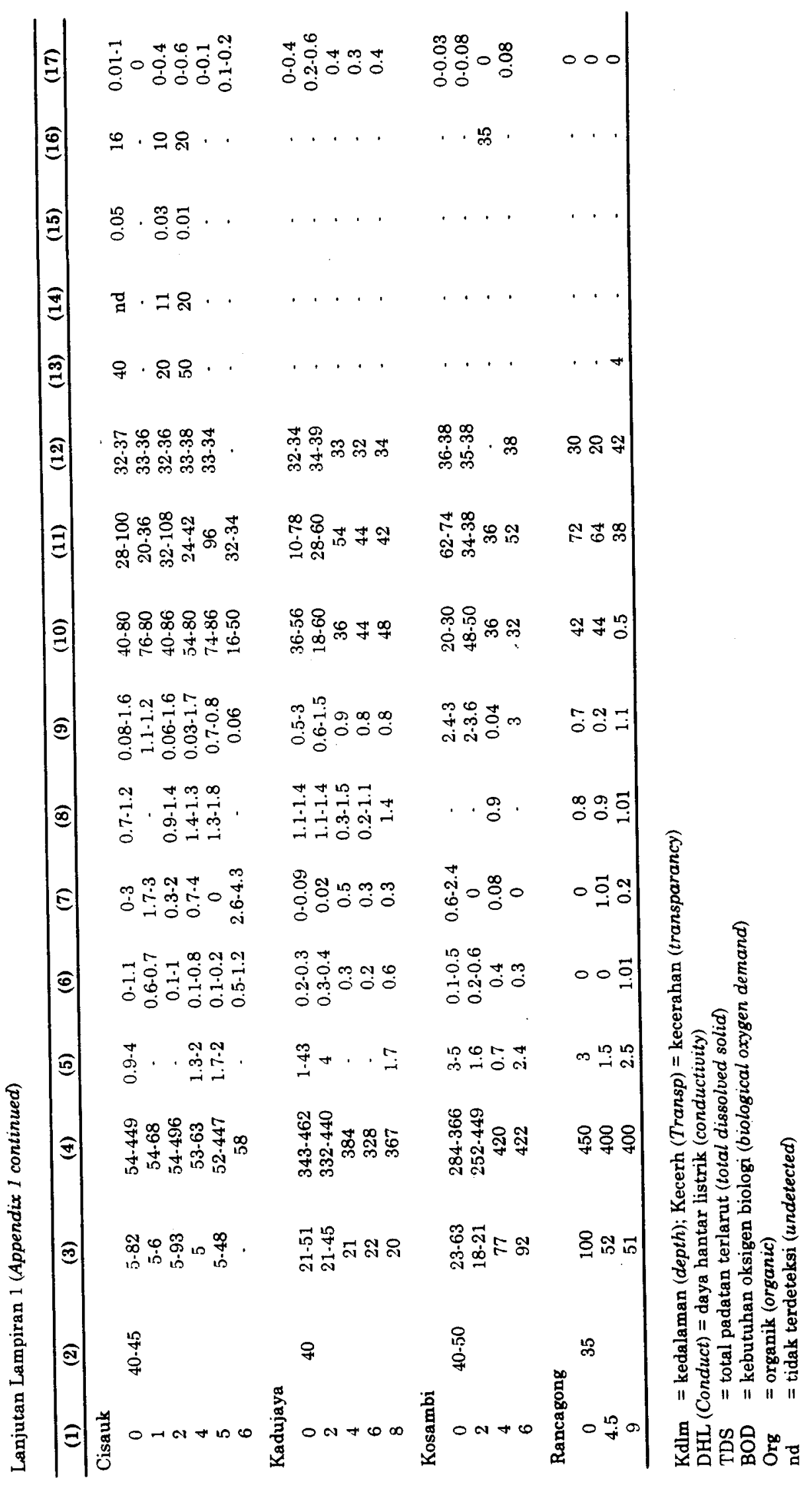


Lampiran 2. Analisis tanah dari bahan dasar perairan kolong bekas galian pasir. Appendix 2. Analysis of bottom soils of sand mining pools.

\begin{tabular}{|c|c|c|c|c|c|c|}
\hline \multirow{2}{*}{$\begin{array}{c}\text { Lokasi } \\
\text { Location }\end{array}$} & \multicolumn{6}{|c|}{ Peubah (Parameter) } \\
\hline & $\begin{array}{l}\text { Tekstur } \\
\text { Texture }\end{array}$ & $\begin{array}{l}\text { Warna } \\
\text { Colour }\end{array}$ & $\begin{array}{c}\text { pH } \\
\text { (unit) }\end{array}$ & $\begin{array}{c}\mathrm{C} \\
(\%)\end{array}$ & $\begin{array}{l}\mathrm{N} \\
(\%)\end{array}$ & $\begin{array}{c}\mathrm{P} \\
(\mathrm{mg} / 100 \mathrm{~g})\end{array}$ \\
\hline Sukadami & $\begin{array}{l}\text { pasir \& lumpur } \\
\text { sand \& mud }\end{array}$ & $\begin{array}{l}\text { hitam } \\
\text { black }\end{array}$ & $5.9 \cdot 7.8$ & $0.07-0.3$ & $0.09-0.8$ & $3.9-4.5$ \\
\hline Sukasari & pasir $(m u d)$ & $\begin{array}{l}\text { hitam } \\
\text { black }\end{array}$ & $5.4-6.5$ & $0.08-0.8$ & $0.2-0.3$ & $3.9-4.5$ \\
\hline Cihuni & pasir (mud) & $\begin{array}{l}\text { hitam } \\
\text { black }\end{array}$ & 4.5 & 0.8 & 0.1 & 3.9 \\
\hline Cisauk & pasir $(m u d)$ & $\begin{array}{l}\text { hitam } \\
\text { black }\end{array}$ & $5.0-5.8$ & $0.7-0.84$ & $0.2-0.53$ & $4.87-5.6$ \\
\hline Kadujaya & pasir $(m u d)$ & $\begin{array}{l}\text { hitam } \\
\text { black }\end{array}$ & 5.9 & 0.08 & 0.2 & 4.8 \\
\hline Kosambi & $\begin{array}{l}\text { pasir \& lumpur } \\
\text { sand \& mud }\end{array}$ & $\begin{array}{l}\text { hitam } \\
\text { black }\end{array}$ & $6.4-7.6$ & $0.07-0.08$ & $0.3-0.8$ & $4.5-4.6$ \\
\hline
\end{tabular}

Lampiran 3. Kelimpahan plankton (ind/L) di perairan kolong bekas galian pasir di Sukadami. Appendix 3. Abundance of plankton (ind $/ L$ ) in sand mining pool of Sukadami.

\begin{tabular}{|c|c|c|c|c|c|c|c|c|c|c|c|c|c|c|c|c|c|c|c|}
\hline \multirow[t]{2}{*}{ Plankton } & \multicolumn{5}{|c|}{ Jul. 1995} & \multicolumn{2}{|c|}{ Sept. 1995} & \multicolumn{5}{|c|}{ Nov. 1995} & \multicolumn{5}{|c|}{ Jan. 1996} & \multicolumn{2}{|c|}{ Feb. 1996} \\
\hline & $0 \mathbf{m}$ & $1 \mathrm{~m}$ & $2 \mathrm{~m}$ & $4 \mathrm{~m}$ & $6 \mathrm{~m}$ & $\mathbf{0} \mathbf{m}$ & $1 \mathrm{~m}$ & $0 \mathrm{~m}$ & $2 \mathrm{~m}$ & $4 \mathrm{~m}$ & $8 \mathbf{m}$ & $10 \mathrm{~m}$ & $0 \mathrm{~m}$ & $2 \mathrm{~m}$ & $4 \mathrm{~m}$ & $8 \mathrm{~m}$ & $12 \mathrm{~m}$ & $\mathbf{0} \mathbf{m}$ & $2 \mathrm{~m}$ \\
\hline \multicolumn{20}{|c|}{ Fitoplankton (Phytoplankton) } \\
\hline \multicolumn{20}{|c|}{ Cyanophyta: } \\
\hline $\begin{array}{l}\text { Oscillatoria } \\
\text { Chlorophyta: }\end{array}$ & 1613 & 768 & 1843 & 1382 & & & . & . & & & . & - & - & - & - & & & 13 & 13 \\
\hline Chlorella & 161 & & & - & & & - & . & . & & . & . & - & . & . & . & . & & . \\
\hline - Cosmarium & - & - & - & - & & & & - & - & & 128 & - & - & . & - & - & . & . & - \\
\hline - Eudorina & 681 & . & 230 & 461 & 27 & 27 & . & 27 & 77 & & 38 & 19 & 13 & & . & & & . & 27 \\
\hline - Pediastrum & - & - & 1613 & 2079 & 70 & 77 & 64 & 58 & 51 & & - & - & - & & & & 38 & & - \\
\hline - Spirogyra & - & . & - & - & 27 & 27 & & 27 & 27 & . & & - & . & & . & & 13 & 26 & \\
\hline - Staurastrum & 691 & - & 922 & 1152 & - & - & - & $\cdot$ & - & . & . & - & . & . & . & . & 27 & & \\
\hline $\begin{array}{l}\text { - Ulothrix } \\
\text { Chrysophyta: }\end{array}$ & & . & - & - & . & 115 & . & & . & . & - & - & - & - & . & . & & & \\
\hline Ceratium & & & & & & - & - & - & - & & - & 77 & 218 & 77 & . & . & 192 & 64 & 74 \\
\hline Diatomae & 691 & 153 & & & & & & - & . & & & 90 & $\cdot$ & 38 & . & . & $\cdot$ & - & $\cdot$ \\
\hline Navicula & - & - & - & - & & . & & & - & 19 & & & . & - & . & . & . & . & . \\
\hline Peridinium & - & 461 & 1382 & 922 & . & . & - & . & . & & & & & & . & . & . & . & . \\
\hline - Synedra & 161 & $\cdot$ & 922 & 1152 & 13 & 70 & 64 & 102 & 51 & & & 90 & 38 & & & & & 13 & 13 \\
\hline \multicolumn{20}{|l|}{$\begin{array}{l}\text { Zooplankton } \\
\text { Rotifera: }\end{array}$} \\
\hline - Asplancha & & & - & & & . & - & . & . & 13 & . & . & . & & . & . & & & \\
\hline - Brachionus & . & & & & & 27 & & - & . & - & . & . & . & . & . & & . & & \\
\hline - Gastropus & & - & & & & & . & & & 13 & & - & . & - & - & & - & . & . \\
\hline - Keratella & . & - & & & 13 & & & & 13 & & & & . & . & . & . & - & & . \\
\hline - Notholca & . & . & - & - & - & - & - & & 26 & & . & 19 & 13 & . & . & . & 26 & & . \\
\hline $\begin{array}{l}\text {-Trichocerus } \\
\text { Copepoda: }\end{array}$ & . & & . & & & . & . & . & & 26 & - & & & & & & & . & . \\
\hline - Diaptomus & - & - & . & . & . & . & . & & . & & . & . & . & . & . & & & . & 13 \\
\hline
\end{tabular}


Lampiran 4. Kelimpahan plankton (ind/L) di perairan kolong bekas galian pasir di Sukasari. Appendix 4. Abundance of plankton (ind/L) of sand mining pool in Sukasari.

\begin{tabular}{|c|c|c|c|c|c|c|c|c|c|c|c|c|c|c|c|c|c|}
\hline \multirow[t]{2}{*}{ Plankton } & \multicolumn{2}{|c|}{ Sept. 1995} & \multicolumn{5}{|c|}{ Nov. 1995} & \multicolumn{5}{|c|}{ Jan. 1996} & \multicolumn{5}{|c|}{ Feb. 1995} \\
\hline & $\mathbf{0} \mathbf{m}$ & $1 \mathrm{~m}$ & $\mathbf{0 ~ m}$ & $2 \mathbf{m}$ & $4 \mathrm{~m}$ & $6 \mathrm{~m}$ & $8 \mathrm{~m}$ & $\mathbf{0 m}$ & $2 \mathbf{m}$ & $4 \mathrm{~m}$ & $8 \mathrm{~m}$ & $10 \mathrm{~m}$ & $\mathbf{0 ~ m}$ & $2 \mathrm{~m}$ & $4 \mathrm{~m}$ & $8 \mathrm{~m}$ & $12 \mathrm{~m}$ \\
\hline \multicolumn{18}{|c|}{ Fitoplankton (Phytoplankton) } \\
\hline Cyanophyta: & & & & & & & & & & & & & & & & & \\
\hline - Anabaena & . & 6400 & - & - & $\therefore$ & 13 & $\cdot$ & • & - & $\cdot$ & $\cdot$ & $\cdot$ & $\cdot$ & - & $\cdot$ & $\cdot$ & · \\
\hline $\begin{array}{l}\text { - Oscillatoria } \\
\text { Chlorophyta: }\end{array}$ & - & - & - & $\cdot$ & 13 & . & $\cdot$ & - & $\cdot$ & $\cdot$ & - & - & · & - & - & - & - \\
\hline - Cosmarium & . & & . & - & . & - & - & - & - & - & . & - & . & 13 & - & . & - \\
\hline - Eudorina & 26 & 13 & 27 & 13 & - & $\cdot$ & $\cdot$ & - & 13 & - & - & 13 & - & 113 & - & - & . \\
\hline - Pediastrum & 26 & 70 & - & 13 & . & $\cdot$ & - & - & - & - & $\cdot$ & - & $\cdot$ & - & - & - & - \\
\hline Spirogyra & - & 38 & . & - & . & - & - & - & - & - & . & . & 90 & - & 26 & . & 13 \\
\hline Staurastrum & . & - & 13 & - & . & . & - & - & 26 & . & - & 13 & $\cdot$ & - & - & $\cdot$ & - \\
\hline $\begin{array}{l}\text { Ulothrix } \\
\text { Chrysophyta: }\end{array}$ & . & 70 & - & . & - & . & - & . & - & - & . & $\cdot$ & $\cdot$ & $\cdot$ & + & . & . \\
\hline - Ceratium & . & . & . & - & - & . & 27 & 563 & 294 & 154 & 218 & 294 & 550 & 486 & 358 & 179 & 410 \\
\hline - Diatomae & . & & - & - & 38 & - & - & - & . & - & · & - & $\therefore$ & 26 & $\cdot$ & $\cdot$ & . \\
\hline - Fragillaria & - & & - & - & - & . & . & - & - & - & - & . & 13 & $\cdot$ & - & - & . \\
\hline - Navicula & - & & 1.3 & - & 13 & . & - & - & . & - & - & - & - & - & - & . & - \\
\hline - Synedra & 64 & 27 & 154 & - & $\cdot$ & 13 & $\cdot$ & - & · & & - & $\cdot$ & . & 13 & 13 & - & - \\
\hline $\begin{array}{l}\text { Zooplankton } \\
\text { Protozoa: }\end{array}$ & & & & & & & & & & & & & & & & & \\
\hline $\begin{array}{l}\text { - Euglena } \\
\text { Rotifera: }\end{array}$ & - & 38 & - & - & . & - & $\cdot$ & • & - & $\cdot$ & $\cdot$ & - & $\cdot$ & $\cdot$ & $\cdot$ & $\cdot$ & $\cdot$ \\
\hline - Keratella & 13 & . & - & - & - & 26 & - & - & - & $\cdot$ & - & - & 13 & $\cdot$ & $\cdot$ & - & · \\
\hline $\begin{array}{l}\text { Notholca } \\
\text { Copepoda: }\end{array}$ & - & . & 26 & - & . & 13 & - & . & . & - & - & - & - & - & 26 & - & . \\
\hline $\begin{array}{l}\text { Diaptomus } \\
\text { Cladocera: }\end{array}$ & . & . & - & . & . & $\cdot$ & - & - & - & - & - & - & - & 13 & . & . & - \\
\hline - Diaphanosoma & - & . & - & . & 13 & - & - & - & - & - & - & - & - & - & $\cdot$ & $\cdot$ & $\cdot$ \\
\hline
\end{tabular}

Lampiran 5. Kelimpahan plankton (ind/L) di perairan kolong bekas galian pasir di Cihuni. Appendix 5. Abundance of plankton (ind/L) of sand mining pool in Cihuni.

\begin{tabular}{|c|c|c|c|c|c|c|c|c|c|c|c|c|c|c|c|c|c|c|}
\hline \multirow[t]{2}{*}{ Plankton } & \multicolumn{4}{|c|}{ Sept. 1995} & \multicolumn{4}{|c|}{ Nov. 1995} & \multicolumn{5}{|c|}{ Jan. 1996} & \multicolumn{5}{|c|}{ Feb. 1996} \\
\hline & $\mathbf{0} \mathbf{m}$ & $1 \mathrm{~m}$ & $2 \mathrm{~m}$ & $4 \mathrm{~m}$ & $0 \mathrm{~m}$ & $2 \mathrm{~m}$ & $4 \mathrm{~m}$ & $7 \mathrm{~m}$ & $0 \mathrm{~m}$ & $2 \mathrm{~m}$ & $4 \mathrm{~m}$ & $8 \mathrm{~m}$ & $10 \mathrm{~m}$ & $0 \mathbf{m}$ & $2 \mathrm{~m}$ & $4 \mathrm{~m}$ & $8 \mathrm{~m}$ & $12 \mathrm{~m}$ \\
\hline \multicolumn{19}{|c|}{ Fitoplankton (Phytoplankton) } \\
\hline $\begin{array}{l}\text { Cyanophyta: } \\
\text { - Oscillatoria } \\
\text { Chlorophyta: }\end{array}$ & 269 & 230 & 80 & 13 & - & - & $\cdot$ & $\cdot$ & $\cdot$ & - & - & $\cdot$ & $\cdot$ & $\cdot$ & $\cdot$ & - & $\cdot$ & $\cdot$ \\
\hline - Cosmarium & 2946 & 234 & 2496 & 678 & 51 & 77 & 13 & 26 & - & - & $\cdot$ & $\cdot$ & - & $\cdot$ & $\cdot$ & . & $\cdot$ & . \\
\hline - Eudorina & 64 & - & $\cdot$ & $\cdot$ & 13 & $\cdot$ & . & - & - & $\cdot$ & · & $\cdot$ & $\cdot$ & in & $\cdot$ & $\cdot$ & $\cdot$ & $\cdot$ \\
\hline - Pediastrum & 38 & 38 & - & . & - & . & - & . & 1.3 & $\cdot$ & $\cdot$ & $\cdot$ & * & 13 & - & - & - & - \\
\hline - Spirogyra & $\cdot$ & - & - & 26 & - & . & - & $\cdot$ & $\cdot$ & $\cdot$ & $\cdot$ & - & - & 26 & - & $\cdot$ & - & . \\
\hline $\begin{array}{l}\text { - Staurastrum } \\
\text { Chrysophyta: }\end{array}$ & • & - & 38 & . & $\cdot$ & . & $\cdot$ & · & $\cdot$ & - & $\cdot$ & - & - & - & - & $\cdot$ & $\cdot$ & $\cdot$ \\
\hline - Ceratium & . & & . & - & - & $\cdot$ & . & - & - & $:$ & - & - & 13 & $\cdot$ & - & - & $\cdot$ & $\cdot$ \\
\hline - Diatomae & 13 & 51 & - & 102 & - & - & . & - & - & $\cdot$ & - & $\cdot$ & $\cdot$ & $\cdot$ & $\cdot$ & $\cdot$ & - & $\cdot$ \\
\hline - Fragillaria & - & $\cdot$ & - & 90 & - & $\cdot$ & . & - & - & - & $\cdot$ & - & $\cdot$ & . & 13 & $\cdot$ & $\cdot$ & $\cdot$ \\
\hline - Navicula & 13 & . & . & $\cdot$ & - & - & - & . & - & 13 & • & $\cdot$ & $\cdot$ & - & - & - & - & $\cdot$ \\
\hline - Peridinium & $\cdot$ & . & - & - & - & . & - & - & - & $\cdot$ & $\cdot$ & · & $\cdot$ & $\cdot$ & 38 & 13 & . & $\cdot$ \\
\hline Synedra & 26 & $\cdot$ & - & 26 & 218 & - & $\cdot$ & $\cdot$ & . & 38 & 13 & $\cdot$ & $\cdot$ & $\cdot$ & - & $\cdot$ & . & - \\
\hline \multicolumn{19}{|l|}{$\begin{array}{l}\text { Zooplankton } \\
\text { Rotifera: }\end{array}$} \\
\hline - Brachionus & . & - & $\cdot$ & - & 13 & . & $\cdot$ & - & $\cdot$ & - & - & . & - & - & - & - & $\cdot$ & $\cdot$ \\
\hline - Hexarthra & . & . & $\cdot$ & $\cdot$ & $\cdot$ & 13 & - & . & . & - & - & · & . & $\cdot$ & $\cdot$ & $\cdot$ & $\cdot$ & $\cdot$ \\
\hline - Notholca & - & . & . & - & 38 & . & . & . & $\cdot$ & 1.3 & 26 & $\cdot$ & $\cdot$ & $\cdot$ & $\cdot$ & - & . & $\cdot$ \\
\hline $\begin{array}{l}\text { Trichocerus } \\
\text { Cladocera: }\end{array}$ & . & $\cdot$ & $\cdot$ & $\cdot$ & $\cdot$ & $\cdot$ & 26 & $\cdot$ & $\cdot$ & $\cdot$ & - & $\cdot$ & $\cdot$ & $\cdot$ & $\cdot$ & - & $\cdot$ & $\cdot$ \\
\hline Bosmina & - & . & . & · & 13 & $\cdot$ & - & $\cdot$ & $\cdot$ & - & - & . & - & $\cdot$ & $\cdot$ & . & $\cdot$ & $\cdot$ \\
\hline
\end{tabular}


Lampiran 6. Kelimpahan plankton (ind/L) di perairan kolong bekas galian pasir di Cisauk.

Appendix 6. Abundance of plankton (ind/L) of sand mining pool in Cisauk.

\begin{tabular}{|c|c|c|c|c|c|c|c|c|c|c|c|}
\hline \multirow[t]{2}{*}{ Plankton } & \multicolumn{5}{|c|}{ Sept. 1898} & \multicolumn{3}{|c|}{ Nov. 1898} & \multicolumn{3}{|c|}{ Jan lenes } \\
\hline & $\mathbf{0 ~ m}$ & $1 \mathbf{~ m}$ & $2 \mathrm{~m}$ & $4 \mathrm{~m}$ & $6 \mathrm{~m}$ & m & $\mathbf{m}$ & $4 \mathrm{~m}$ & $\mathbf{0} \mathbf{m}$ & $8 m$ & $8 \mathrm{~m}$ \\
\hline \multicolumn{12}{|c|}{ Fitoplankton (Phytoplankton) } \\
\hline \multicolumn{12}{|l|}{ Cyanophyta: } \\
\hline Anaboena & . & - & - & - & . & . & 13 & - & 38 & $\mathbf{3 8}$ & 188 \\
\hline Microcystis & . & - & - & 282 & . & - & . & - & - & - & - \\
\hline - Oscillataria & . & - & . & - & . & . & . & . & 108 & 39 & 140 \\
\hline \multicolumn{12}{|l|}{ Chlorophyta } \\
\hline - Bulbochaete: & . & . & - & - & . & - & . & - & - & . & 27 \\
\hline - Cosmarium & . & 51 & - & - & - & 26 & - & . & . & - & . \\
\hline - Eusdorina & 51 & 19 & 32 & 90 & 32 & 38 & 12 & . & 48 & 13 & 13 \\
\hline - Pediastrum & 32 & 13 & 13 & 9) & 122 & - & . & . & , & - & - \\
\hline - Spirogyra & 166 & 64 & 51 & 15 & 51 & 19 & . & 51 & 78 & 77 & 102 \\
\hline - Staurastrum & - & $\cdot$ & - & 218 & . & - & . & $\cdot$ & ? & - & 13 \\
\hline - Tetraedron & - & 51 & - & - & . & . & . & . & . & - & , \\
\hline Ulothrix & . & . & . & 13 & . & . & . & v & v & 13 & 13 \\
\hline \multicolumn{12}{|l|}{ Chrysophyta: } \\
\hline - Ceralium & - & - & 13 & - & $=$ & - & . & - & * & , & 13 \\
\hline - Diatomae & 13 & $\cdot$ & 19 & $=$ & - & - & 90 & $\cdot$ & * & , & , \\
\hline - Navicula & $\cdot$ & . & - & - & - & - & $\cdot$ & - & 13 & 28 & 18 \\
\hline - Synedra & 32 & . & 19 & 45 & 32 & 13 & . & . & , & - & - \\
\hline \multicolumn{12}{|l|}{$\begin{array}{l}\text { Zooplankton } \\
\text { Protozoa: }\end{array}$} \\
\hline - Arcella & - & - & - & . & . & - & - & . & . & - & 8 \\
\hline Rotifera: & & & & & & & & & & & \\
\hline - Brachionus & $\cdot$ & 13 & $\cdot$ & v & - & • & 13 & $=$ & ? & • & v \\
\hline - Hexarthra & . & 13 & • & $\cdot$ & $\cdot$ & • & • & ? & v & , & $\checkmark$ \\
\hline - Keratella & - & $\cdot$ & • & . & - & - & . & - & 13 & - & 18 \\
\hline - Notholca & . & $\cdot$ & - & . & 13 & - & 19 & $\cdot$ & . & , & 19 \\
\hline $\begin{array}{l}\text { Trichocerca } \\
\text { Cladocera: }\end{array}$ & - & - & . & 13 & $\cdot$ & - & - & . & , & - & , \\
\hline - Cyclops & - & - & - & . & . & 19 & . & - & . & - & - \\
\hline - Diaptomus & . & . & . & - & . & - & . & . & . & . & 13 \\
\hline
\end{tabular}


Lampiran 7. Kelimpahan plankton (ind/L) di perairan kolong bekas galian pasir di Kosambi, Kadujaya dan Rancagong.

Appendix 7. Abundance of plankton (ind/L) of sand mining pools in Kosambi, Kadujaya and Rancagong.

\begin{tabular}{|c|c|c|c|c|c|c|c|c|c|c|c|c|c|c|}
\hline \multirow[t]{3}{*}{ Plankton } & \multirow{2}{*}{\multicolumn{4}{|c|}{$\begin{array}{l}\text { Kosambi } \\
\text { Jul. } 1995\end{array}$}} & \multicolumn{7}{|c|}{ Kadujaya } & \multirow{2}{*}{\multicolumn{3}{|c|}{$\begin{array}{c}\text { Rancagong } \\
\text { Jan. } 1996\end{array}$}} \\
\hline & & & & & \multicolumn{2}{|c|}{ Sept. 1995} & \multicolumn{5}{|c|}{ Jan. 1996} & & & \\
\hline & $0 \mathrm{~m}$ & $2 \mathrm{~m}$ & $4 \mathrm{~m}$ & $6 \mathrm{~m}$ & $0 \mathrm{~m}$ & $2 \mathrm{~m}$ & $0 \mathbf{~ m}$ & $2 \mathrm{~m}$ & $4 \mathrm{~m}$ & $6 \mathrm{~m}$ & $8 \mathrm{~m}$ & $\mathbf{0} \mathbf{m}$ & $4.5 \mathrm{~m}$ & $9 \mathrm{~m}$ \\
\hline \multicolumn{15}{|c|}{ Fitoplankton (Phytoplankton) } \\
\hline \multicolumn{15}{|l|}{ Cyanophyta: } \\
\hline - Anabaena & 1115 & 268 & 7040 & 666 & 6758 & 2816 & - & - & - & - & - & - & - & . \\
\hline $\begin{array}{l}\text { - Oscillatoria } \\
\text { Chlorophyta: }\end{array}$ & 3898 & 2880 & 5760 & 998 & 4506 & 4506 & . & - & . & - & . & . & 26 & 13 \\
\hline Chlorella & 1856 & 1344 & 8320 & 1331 & 6758 & 5094 & - & - & . & - & . & . & . & . \\
\hline Cosmarium & - & - & - & - & & & 19 & 19 & - & . & . & - & - & - \\
\hline - Eudorina & 1114 & 588 & 5120 & 333 & 6758 & 1690 & 64 & - & - & - & 13 & . & 13 & . \\
\hline - Pediastrum & 371 & . & 4480 & 333 & 2252 & 1690 & 45 & - & 13 & 26 & ? & . & - & - \\
\hline - Spirogyra & 1670 & 2650 & 5760 & 667 & 2816 & 2253 & - & - & - & - & 26 & . & . & - \\
\hline $\begin{array}{l}\text { - Tetraedron } \\
\text { Chrysophyta: }\end{array}$ & cor & . & & - & - & 句山 & 13 & . & * & - & $\cdot$ & - & - & - \\
\hline - Ceratium & - & . & 1180 & - & 1690 & 1690 & 38 & . & . & - & . & 38 & 26 & 64 \\
\hline - Diatomae & - & - & • & - & - & $\cdot$ & 32 & 19 & 64 & 77 & 102 & - & - & - \\
\hline - Navicula & - & . & . & - & 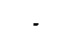 & & . & . & 13 & 13 & 13 & . & . & - \\
\hline - Peridinium & 557 & 390 & 3200 & 667 & 3942 & 4506 & . & - & - & - & - & . & . & . \\
\hline Synedra & 742 & 435 & 4480 & 333 & 1126 & 1690 & - & 51 & - & - & - & - & - & - \\
\hline \multicolumn{15}{|l|}{ Zooplankton } \\
\hline Basillus & . & . & . & . & 2816 & 3379 & . & . & . & . & . & . & . & - \\
\hline $\begin{array}{l}\text { Phacus } \\
\text { Rotifera: }\end{array}$ & - & - & 7680 & . & - & - & . & . & - & . & . & . & . & . \\
\hline - Asplancha & 557 & 294 & 3200 & - & 4506 & 3379 & . & . & - & . & . & . & . & . \\
\hline - Hexarthra & 371 & - & 2960 & - & - & - & . & . & - & . & - & . & . & . \\
\hline Keratella & 371 & - & 4480 & 998 & 4506 & 3942 & 13 & - & 13 & - & - & - & . & . \\
\hline - Notholca & 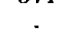 & . & - & $\therefore$ & - & - & - & 13 & - & . & . & . & - & . \\
\hline $\begin{array}{l}\text {-Ratulus-ratus } \\
\text { Copepoda: }\end{array}$ & 371 & - & 3840 & 333 & 6758 & 2816 & . & . & . & . & . & - & . & . \\
\hline Cyclops & - & - & - & - & 13 & . & . & - & - & . & . & . & . & . \\
\hline - Diaptomus & . & - & 1920 & . & - & - & - & . & - & . & . & . & . & . \\
\hline
\end{tabular}




\title{
LOKASI-LOKASI POTENSIAL BAGI PANTI BENIH TERAPUNG IKAN KARANG DI SELATAN P. BINTAN DAN KARIMUN JAWA
}

\author{
Wardana Ismail $^{*}$, Supriyono Eko Wardoyo ${ }^{\star)}$ dan Bambang Priono*)
}

\begin{abstract}
ABSTRAK
Survai lokasi bagi penempatan Panti Benih Terapung ikan karang telah dilakukan di perairan Selatan P. Bintan Karimun Jawa, pada periode Mei-Juli 1996. Penelitian ini dilakukan atas dasar parameter yang telah ditentukan baik teknis maupun nonteknis, meliputi kualitas air, kesuburan air, ekosistem, ketersediaan induk dan kemudahan mencapai lokasi, bahan KJA, tenaga kerja, keamanan, sarana, masyarakat, pasar. Dalam penelitian di lapangan tim peneliti dilengkapi dengan alat GPS (Global Positioning System) untuk menentukan posisi (Lintang dan Bujur) yang tepat di laut.

Dengan perbandingan bobot parameter teknis dengan nonteknis 5,5:4,5 serta ranking penilaian antara 1-5 tergantung pentingnya parameter yang diamati dalam penentuan lokasi Panti Benih, maka diperoleh hasil bahwa perairan Selatan P. Bintan (Kepulauan Riau) memiliki lokasi yang lebih baik daripada perairan kepulauan Karimun Jawa. Khusus perairan di Selatan P. Bintan, lokasi sekitar perairan Pulau Sirai memiliki skor paling tinggi, yaitu 512,5. Dengan demikian, bagi penempatan Panti Benih Terapung ikan karang maka lokasi perairan Pulau Sirai, Selatan P. Bintan di Kepulauan Riau sangat potensial untuk dikembangkan.
\end{abstract}

ABSTRACT: Potential sites for floating hatchery of coral fish in Southern Bintan Island, Riau and Karimun Jawa waters.by: Wardana Ismail, Supriyono Eko Wardoyo and Bambang Priono.

Site selection surveys for floating hatchery of coral fish were conducted from May to July 1996 in Riau and Karimun Jawa waters. Surveys were conducted based on technical and non-technical factors, such as water quality, fertility, ecosystem, broodstock, and accessibility, man power, security, infrastructure, society, and market demand. The survey team was equipped with GPS (Global Positioning System) to determine accurate positions in the sea

Values of the technical and nontechnical factor were weighted 5.5:4.5 and ranking scores were between 1-5 depending on the importance of observed parameters. It was resulted that Southern Bintan Island waters were better than Karimun Jawa. In Southern Bintan Island, location surrounding Sirai Island had the highest score $(512,5)$ compare to other locations, that means Sirai Island waters are very potential for the development of floating hatchery for coral fish.

KEYWORDS: Floating Hatchery, site selection, coral fish, Bintan Island, Karimun Jawa.

\section{PENDAHULUAN}

Budidaya ikan laut sangat prospektif pengembangannya di Indonesia yang memiliki sumber daya perairan dan beragam komoditasnya. Namun demikian sampai saat ini sebagian pasokan benih bagi kegiatan budidaya laut khususnya ikan karang, masih mengandalkan pada benih alam yang tidak terjamin mutu, jumlah dan kontinyuitas ketersediaannya. Teknologi pembenihan beberapa jenis ikan karang seperti kakap putih, kerapu lumpur, kerapu macan, kerapu sunu, beronang, kerapu bebek, atau lemak telah dikuasai (Sugama \& Wiyono, 1955). Namun demikian pembenihan buatan yang dilakukan di darat (land based) masih menghadapi kendala pemeliharaan larva, penyediaan jasad pakan dan pendederan di samping memerlukan lahan dan fasilitas pembenihan dengan biaya tinggi. Panti benih terapung ikan karang semi alami adalah salah satu usaha penanggulangan masalah tersebut. Pemanfaatan sumber daya alam yaitu

\footnotetext{
Peneliti pada Pusat Penelitian dan Pengembangan Perikanan
} 
lingkungan yang bebas cemaran, pakan alami yang sesuai dengan kebutuhan dan kualitas air akan menunjang keberhasilan dan pengembangan panti benih semi alami ini.

Sejak tahun 1978 di wilayah Riau telah berkembang budidaya ikan kerapu dengan sistem Keramba Jaring Apung (KJA). Usaha ini berkembang karena dukungan pasar di P. Bintan, Batam, Singapura dan Hongkong. Hingga saat ini tercatat sekitar 1500 kurungan apung (Mintardjo et al., 1995) telah dikembangkan di perairan tersebut. Jenis-jenis ikan yang dibudidayakan adalah kerapu sunuk, kerapu lumpur, kakap merah, ikan lemak dan kakap putih (Lamidi, 1992; Asmaneli \& Masril, 1992; Mintardjo, 1995). Usaha budidaya tersebut memerlukan pasok benih yang cukup besar, yang diperkirakan mencapai 3 juta ekor ikan/tahun. Untuk ikan kakap putih saja, P.T. Buru Karimun Mandiri memerlukan 6 ton per tahun (Elon, 1995). Pengembangan panti-panti terapung di wilayah usaha budidaya ikan tentu akan sangat menguntungkan karena semakin pendeknya jarak pasok benih. Hal ini menguntungkan selain harga benih yang menjadi lebih rendah, juga mutu benih akan lebih tinggi karena benih tidak mengalami stres karena pengaruh pengangkutan. Untuk mendukung pengembangan panti-panti benih tersebut tentunya diperlukan lokasi yang tepat, yang memenuhi persyaratan produksi benih ikan.

Ismail et al. (1996) telah melakukan penelitian untuk menyeleksi lokasi yang sesuai bagi reservat ikan di Kepulauan Riau, dan hasilnya perairan Duku, Dompak, Muara Sungai Betung adalah yang paling ideal bagi penempatan KJA reservat sebagai penampungan induk kerapu. Dari hasil penelitian tersebut diperkirakan Kepulauan Riau juga sesuai bagi penempatan KJA sebagai panti benih terapung. Dalam pemilihan lokasi, Ismail et al. (1966) melakukan penilaian terhadap karakter perairan, dengan mangacu pada persyaratan suatu perairan bagi reservat ikan. Metode ini diperkirakan dapat pula digunakan untuk menilai kesesuaian suatu lokasi perairan bagi panti benih, dengan menggunakan persyaratan panti benih sebagai acuan.

Kegiatan penelitian identifikasi perairan yang potensial untuk penempatan KJA panti benih berikut pengembangannya dilaksanakan di dua lokasi yaitu di perairan Kepulauan Riau, Propinsi Riau dan perairan Kepulauan Karimun Jawa,
Kabupaten Jepara, Propinsi Jawa Tengah. Sehubungan dengan SK Menhut No. 123/KptsII/1986 yang menetapkan bahwa Kepulauan Karimun Jawa sebagai daerah cagar alam, serta SK Menhut No. 116/Menhut II/1988 yang menyatakan Kepulauan Karimun Jawa merupakan 'Taman Laut Nasional (TLN) yang terbagi atas empat mintakad (wilayah), yaitu: 1). mintakad inti, 2). mintakad perlindungan, 3). mintakad pemanfaatan, dan 4). mintakad penyangga, maka lokasi yang digunakan dalam penelitian ini dipilih yang terletak di mintakad pemanfaatan. Hasil penelitian diharapkan dapat dimanfaatkan untuk pengembangan teknologi KJA panti benih semi alami dan pemanfaatan sumber daya alam perairan untuk perikanan budidaya.

\section{BAHAN DAN METODE PENELITIAN}

Lokasi-lokasi penelitian di perairan Selatan Bintan dan Karimun Jawa dipilih berdasarkan peta wilayah kepulauan Riau dan Karimun Jawa. Berdasarkan peta tersebut, lokasi dipilih dengan mempertimbangkan beberapa faktor penting seperti lokasi selat yang biasanya cocok untuk KJA, adanya pemukiman penduduk dan bukan alur lalulintas kapal-kapal besar, serta keberadaan usaha budidaya ikan karang. Penajaman seleksi lokasi penelitian dilakukan melalui wawancara dengan aparat terkait atau nelayan setempat yang memiliki informasi mengenai sifat dan kondisi perairan serta menguasai permasalahan budidaya ikan di daerah tersebut.

Berdasarkan pertimbangan yang telah disebutkan, lokasi yang dipilih untuk diamati potensinya dalam penelitian ini adalah: a) Selat antara Pulau Alang dan Pulau Mantang, b) Selat antara Pulau Kekip dan Pulau Mantang, dan c) Selat antara Pulau Sirai dan Pulau Senjolong Besar, untuk perairan Selatan P. Bintan (Gambar 1), serta d) selat antara P. Menjangan Besar dan P. Menjangan Kecil, e) Teluk Legon Boyo, dan f) selat antara P. Karimun Jawa dengan P. Menjangan Besar untuk perairan Karimun Jawa (Gambar 2). Lokasi-lokasi tersebut di samping merupakan selat yang umumnya cocok untuk KJA juga merupakan daerah pemukiman penduduk sehingga dapat menunjang berjalannya panti benih serta tidak di lalui kapal-kapal besar yang kemungkinan dapat menimbulkan pencemaran. 


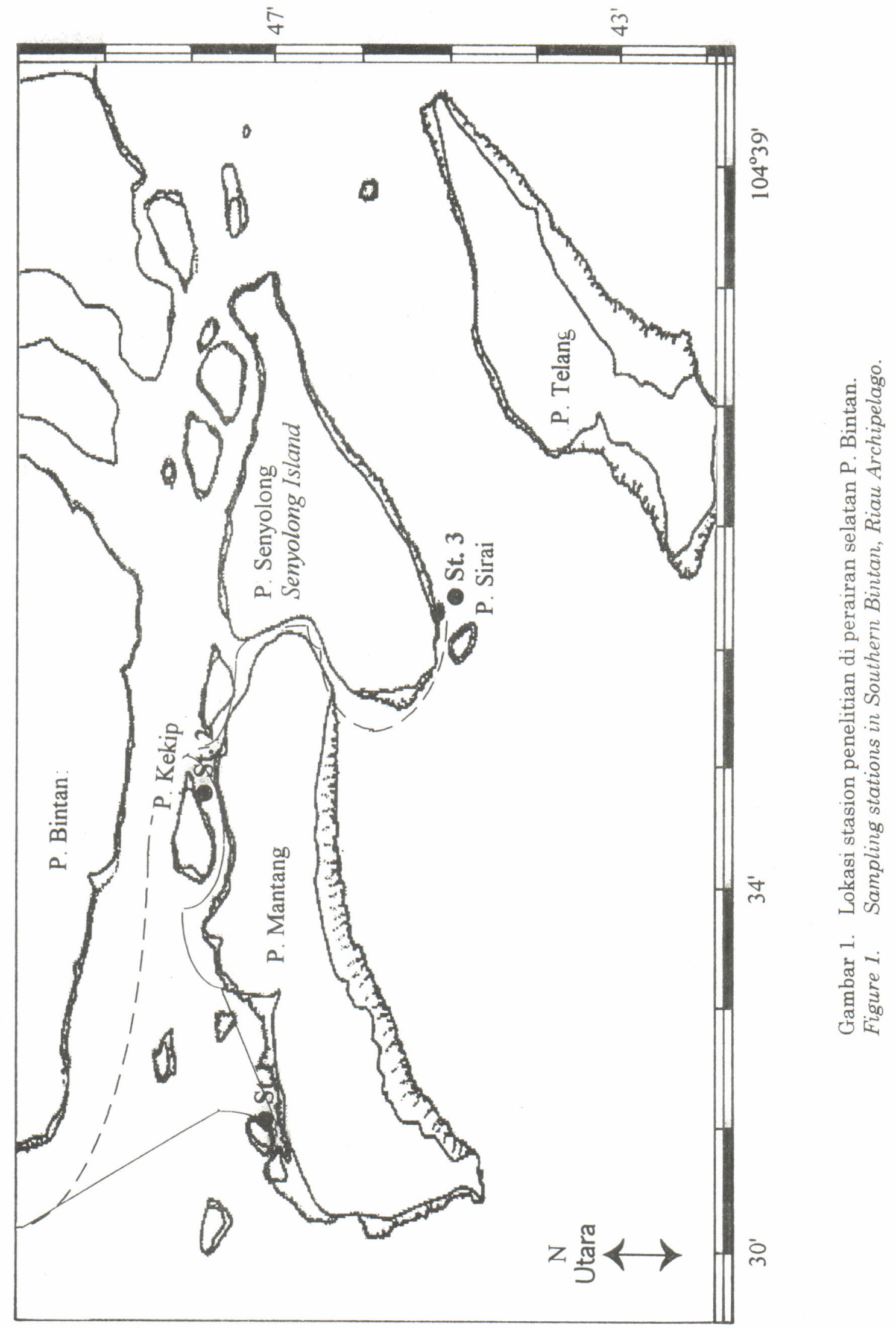




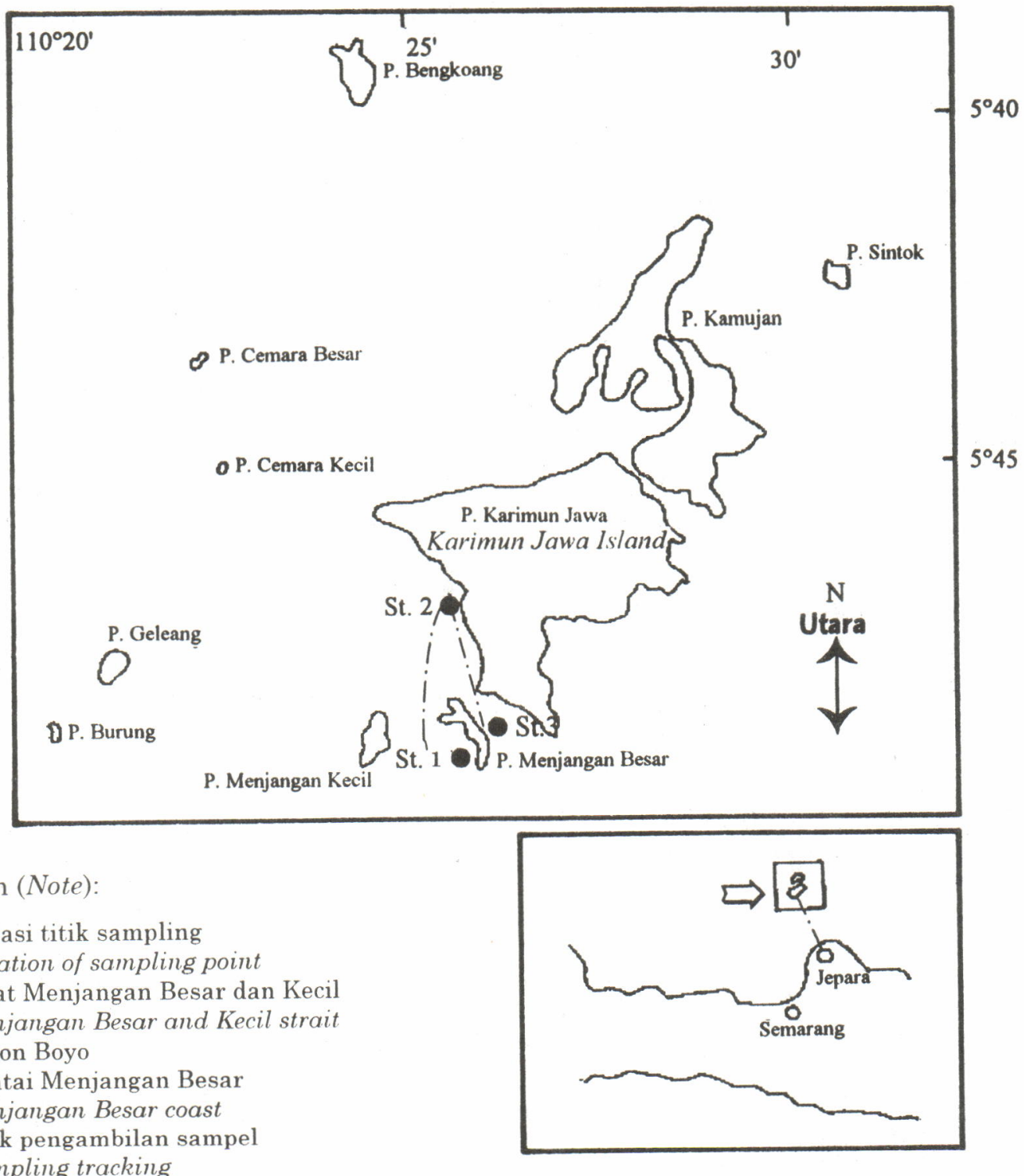

Keterangan (Note):

Lokasi titik sampling

Location of sampling point

St. 1 : Selat Menjangan Besar dan Kecil

Menjangan Besar and Kecil strait

St. 2 : Legon Boyo

St. 3 : Pantai Menjangan Besar

Menjangan Besar coast

-.- : Trak pengambilan sampel

Sampling tracking

Gambar 2. Lokasi stasion sampling di perairan Karimun Jawa.

Figure 2. Sampling location of Karimun Jawa waters.

Dalam seleksi lokasi dilakukan pengukuran dan penilaian parameter teknis dan nonteknis. Masing-masing parameter tersebut diberi perbandingan bobot berbeda, yaitu untuk faktor teknis 5,5 dan nonteknis 4,5 dengan nilai 1,3 , dan 5 tergantung pentingnya parameter tersebut dalam penentuan lokasi KJA panti benih. Skor terakhir dari suatu lokasi adalah jumlah skor parameter-parameter yang didapatkan dari hasil perkalian antara nilai dan bobot (skor parameter = nilai $\mathrm{x}$ bobot). Akhirnya akan didapatkan skor yang berbeda pada setiap lokasi yang diteliti. Skor yang tertinggi dari suatu lokasi adalah merupakan lokasi yang terpilih. Sistem skoring seperti tersebut dalam pemilihan lokasi mengacu metode untuk pemilihan lokasi bagi keramba jaring apung reservat yang dilakukan oleh Ismail et al. (1996).

Dalam penelitian di lapangan tim peneliti dilengkapi dengan alat GPS (Global Positioning System) untuk menentukan posisi (Lintang dan Bujur) di laut, dan alat-alat lain untuk penentuan (pengamatan) kualitas air.

Parameter teknis yang diamati adalah kualitas air, kesuburan perairan, morfologi 
Ismail, W.; Supriyono, E.W.; dan Bambang P.

perairan dan ekosistem, serta ketersediaan induk ikan karang, sedangkan parameter nonteknis adalah aksesibilitas lokasi, ketersediaan bahan
KJA, tenaga kerja, keamanan, ketersediaan sarana pendukung, perilaku masyarakat sekitar, dan permintaan benih ikan (Tabel 1).

Tabel 1. Penentuan nilai berdasarkan parameter teknis dan non teknis.

Tabel 1. Scoring based on techical and non technicaal parameters.

\begin{tabular}{ccccc}
\hline Parameter (Parameters) & \multicolumn{3}{c}{ Nilai (Score) } \\
\cline { 2 - 4 }
\end{tabular}

I. Teknis (Technical aspects) (bobot/weight : 5,5)

1. Kualitas air (Water quality) :

- Kedalaman (Depth)

- Kecerahan (Transparancy)

- Salinitas (Salinity)

- Oksigen terlarut (Disolved Oxygen)

- $\mathrm{pH}$

- Suhu air (Water temperature)

- Arus air (Water current)

- Gelombang (Waves)

- Tanah dasar (Bottom soil)

$$
\begin{gathered}
<3 \mathrm{~m} \\
<1 \mathrm{~m} \\
<20 \mathrm{ppt} \\
<4 \mathrm{ppm} \\
<5 \\
<25 \mathrm{atau}>32 \\
>20 \mathrm{~cm} / \mathrm{dt} \\
>30 \mathrm{~cm} \\
\text { Lumpur (clay) }
\end{gathered}
$$

$$
\text { sedikit (low) }
$$$$
\text { sedikit (low) }
$$

Varlety and density of plankton

Keragaan dan jumlah ikan rucah Density and abundance of trash fish

3. Morfologi dan ekosistem (Morphology and ecosystem)

- Morfologi (Morphology)

- Keberadaan bakau, lamun, dan terumbu karang (Density of mangrove, seagrass, and coral reefs)

- Jarak ke pantai (Dinstance to coast line)

4. Ketersediaan induk ikan karang Availability of coral fish broodstock

$$
\begin{aligned}
& \text { terbuka (open) } \\
& \begin{array}{c}
\text { tidak ada/jarang } \\
\text { low } \\
<50 \mathrm{~m}
\end{array}
\end{aligned}
$$

sulit/sedikit (low)

$3-5 \mathrm{~m}$
$1-3 \mathrm{~m}$
$20-30 \mathrm{ppt}$
$5-6 \mathrm{ppm}$
$5-7$
$25-27$
$10-20 \mathrm{~cm} / \mathrm{dt}$
$20-30 \mathrm{~cm}$
sanpur berpasir
sandy clay

$>5 \mathrm{~m}$

$>3 \mathrm{~m}$

$>30 \mathrm{ppt}$

$>7$ ppm

$>7$

28-32

$<10 \mathrm{~cm} / \mathrm{dt}$

$<20 \mathrm{~cm}$

Pasir lumpur sand

$$
\begin{aligned}
& \text { sedang (moderate) banyak (high) } \\
& \text { sedang (moderate) banyak (high) }
\end{aligned}
$$

cukup terlindung moderately closed cukup padat moderate

$$
>200 \mathrm{~m}
$$$$
50-200 \mathrm{~m}
$$

terlindung closed padat (high)

cukup mudah/ mudah/banyak sedang (moderate) high

II. Nonteknis (Non technical aspects) (bobot/weight : 4.5)

1. Aksesibilitas lokasi (Accessability of location)

2. Ketersediaan bahan KJA Availability of materials for cage

3. Tenaga kerja (Availability of labour)

4. Keamanan (Security)

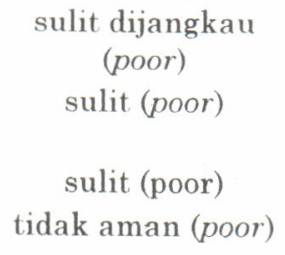

agak sulit dijangkau (fair) agak sulit (fair)

agak sulit (fair) agak aman (fair) mudah dijangkau (good) mudah (good)

mudah (good) aman (good) 
Tabel 1. Lanjutan

Table 1. Continued

\begin{tabular}{|c|c|c|c|}
\hline \multirow{2}{*}{ Parameter (Parameters) } & \multicolumn{3}{|c|}{ Nilai (Score) } \\
\hline & 1 & 3 & 5 \\
\hline $\begin{array}{l}\text { 5etersediaan sarana pendukung: listrik, } \\
\text { komunikasi, pasar, pabrik es, dll. } \\
\text { Availability of supporting facilities: } \\
\text { electricity, communication, market, ice } \\
\text { making plant, etc.) }\end{array}$ & $\begin{array}{l}\text { tidak ada/sedikit } \\
\text { poor }\end{array}$ & $\begin{array}{l}\text { sebagian tersedia } \\
\text { fair }\end{array}$ & $\begin{array}{l}\text { lengkap } \\
\text { good }\end{array}$ \\
\hline $\begin{array}{l}\text { 6. Hasrat petani ikan untuk maju } \\
\text { Attitude of fish farmers }\end{array}$ & rendah (poor) & sedang (fair) & tinggi (good) \\
\hline $\begin{array}{l}\text { 7. Permintaan benih ikan (Demand for fish } \\
\text { seed) }\end{array}$ & $\begin{array}{l}\text { tidak ada/ } \\
\text { rendah (low) }\end{array}$ & sedang (moderate) & tinggi (high) \\
\hline
\end{tabular}

\section{HASIL DAN PEMBAHASAN}

Hasil penelitian terhadap parameter-parameter yang diukur menunjukkan bahwa lokasi selatan P. Bintan mendapatkan skor 979 untuk faktor teknis dan 319,5 untuk faktor nonteknis atau total 1298,5, sedangkan lokasi P. Karimun Jawa memperoleh skor total 950,5 yang terdiri atas 793 dari faktor teknis dan 157,5 dari nonteknis (Tabel 2 dan 3). Dari tabel-tabel tersebut terlihat bahwa daerah selatan P. Bintan mempunyai potensi yang lebih tinggi untuk digunakan sebagai lokasi panti benih. Untuk daerah selatan P. Bintan, dari tiga lokasi yang diamati ternyata lokasi di antara P. Sirai dan P. Senjolong Besar adalah yang terbaik karena memperoleh skor 364 untuk faktor teknis, dan 148,5 untuk faktor non teknis. Adapun untuk perairan Karimun Jawa, lokasi di dekat P. Menjangan Besar adalah yang terbaik dibandingkan dua lokasi lain, walaupun skornya masih jauh di bawah skor untuk lokasi di dekat P. Sirai di selatan P. Bintan.

Kedalaman perairan di enam lokasi di kedua wilayah (selatan P. Bintan dan Karimun Jawa) berkisar antara 5-16 m, dan semuanya memenuhi syarat bagi penempatan panti benih terapung. Kecerahan dan suhu air di selatan P. Bintan memang sedikit lebih rendah (masing-masing sekitar 2-2,5 $\mathrm{m}$ dan $27-27,5^{\circ} \mathrm{C}$ ) dibandingkan dengan di Karimun Jawa yang mencapai masingmasing 5-7 $\mathrm{m}$ dan $29-31^{\circ} \mathrm{C}$. Kedua wilayah perairan pada umumnya berdasar pasir, kecuali lokasi P.Alang yang mempunyai dasar lumpur dan lokasi Boyo yang mempunyai dasar lumpur berpasir. Warna air juga rata-rta hijau atau hijau kebiruan yang jernih kecuali lokasi di dekat P.Kekip yang terlihat keruh.
Arus air di Karimun Jawa mempunyai skor yang lebih rendah dibandingkan dengan selatan Bintan. Selebihnya, salinitas, oksigen terlarut dan $\mathrm{pH}$ di ke enam lokasi dinilai cukup bagus bagi kehidupan ikan karang. Dari segi morfologi, lima lokasi dinilai cukup bagus karena merupakan selat yang tertutup, hanya lokasi di $\mathrm{P}$. Menjangan Kecil yang kurang memenuhi syarat. Secara umum, perairan Karimun Jawa tidak sebaik selatan P. Bintan dilihat dari jenis dan kerapatan plankton (Tabel 4), ketersediaan ikan rucah dan keberadaan hutan bakau. Namun demikian, terumbu karang hanya ditemukan di Karimun Jawa, tidak di selatan P. Bintan. Selain itu, perairan Karimun Jawa tidak didukung dengan ketersediaan induk ikan karang, kemudahan dalam mendapatkan tenaga kerja maupun bahan untuk KJA serta fasilitas pendukung lainnya. Lebih jauh, wilayah ini mempunyai aksesibilitas yang rendah, keamanan yang kurang terjamin, perilaku masyarakat petani ikan yang masih rendah dan permintaan benih yang juga rendah.

Untuk lokasi selatan P. Bintan, perairan di dekat P. Sirei memang lebih unggul dalam ketersediaan plankton sebagai sumber jasad pakan bagi benih ikan, ketersediaan induk, material untuk KJA, tenaga kerja, dan fasilitas pendukung lainnya. Di samping itu, permintaan pasar akan benih di daerah tersebut memang tinggi dan ini mempengaruhi sikap petani ikan dalam merespon teknologi pembenihan ikan.

Adapun untuk lokasi Karimun Jawa, satusatunya keunggulan lokasi P. Menjangan Besar dibandingkan dengan dua lokasi lainnya adalah perilaku masyarakat petani ikan di sekitar lokasi percobaan, yang tampak memberikan respon positif. 


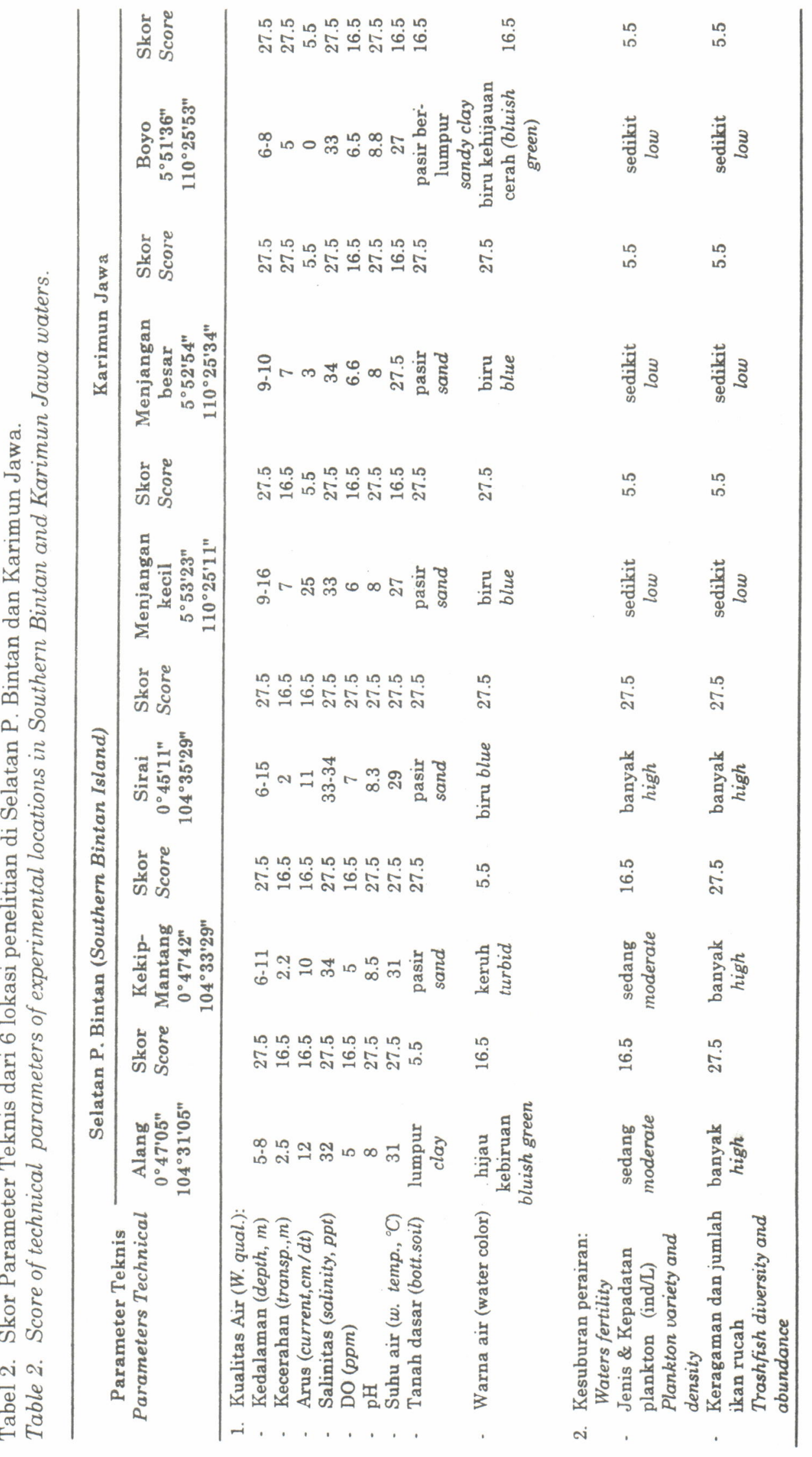




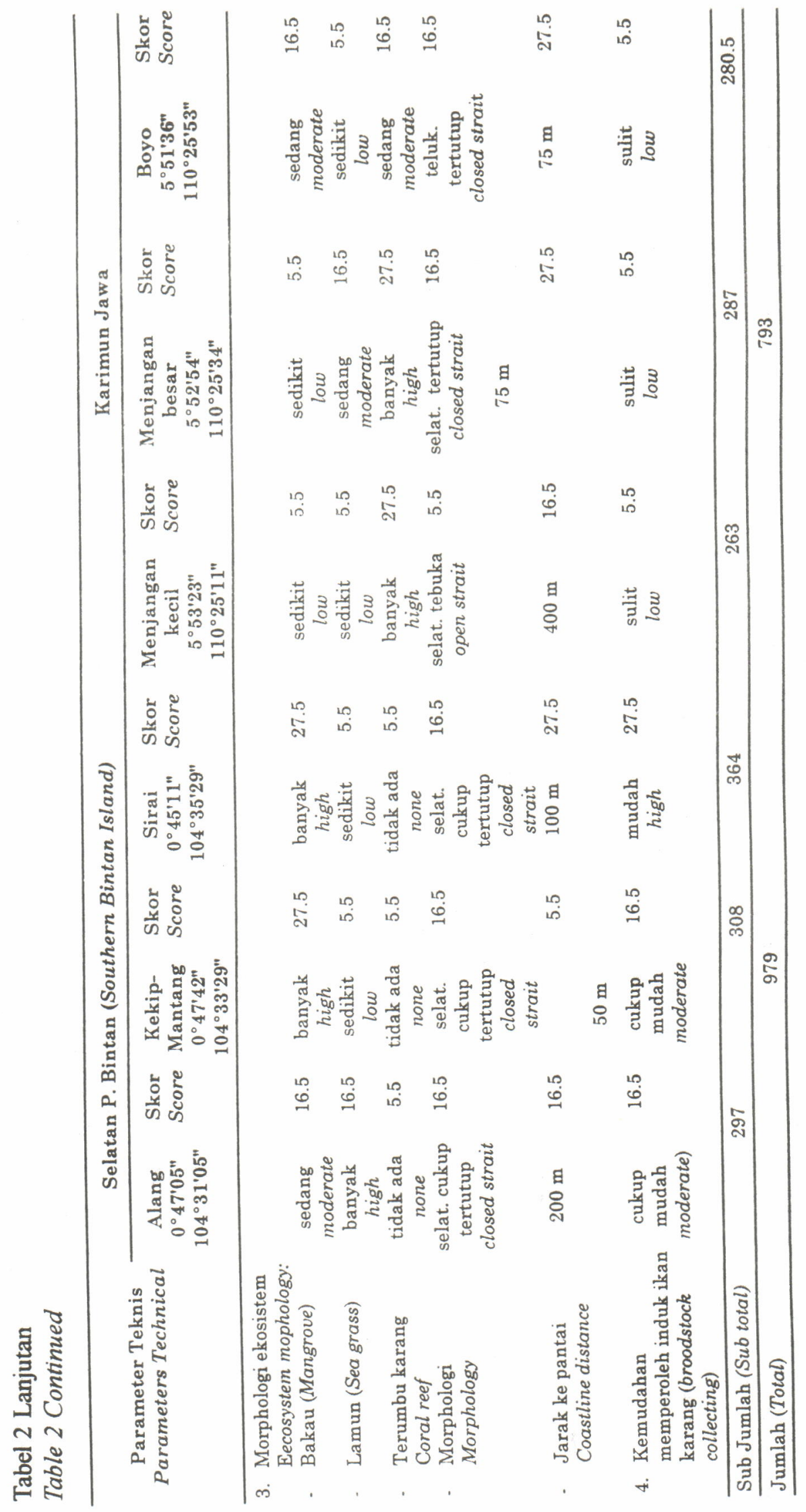




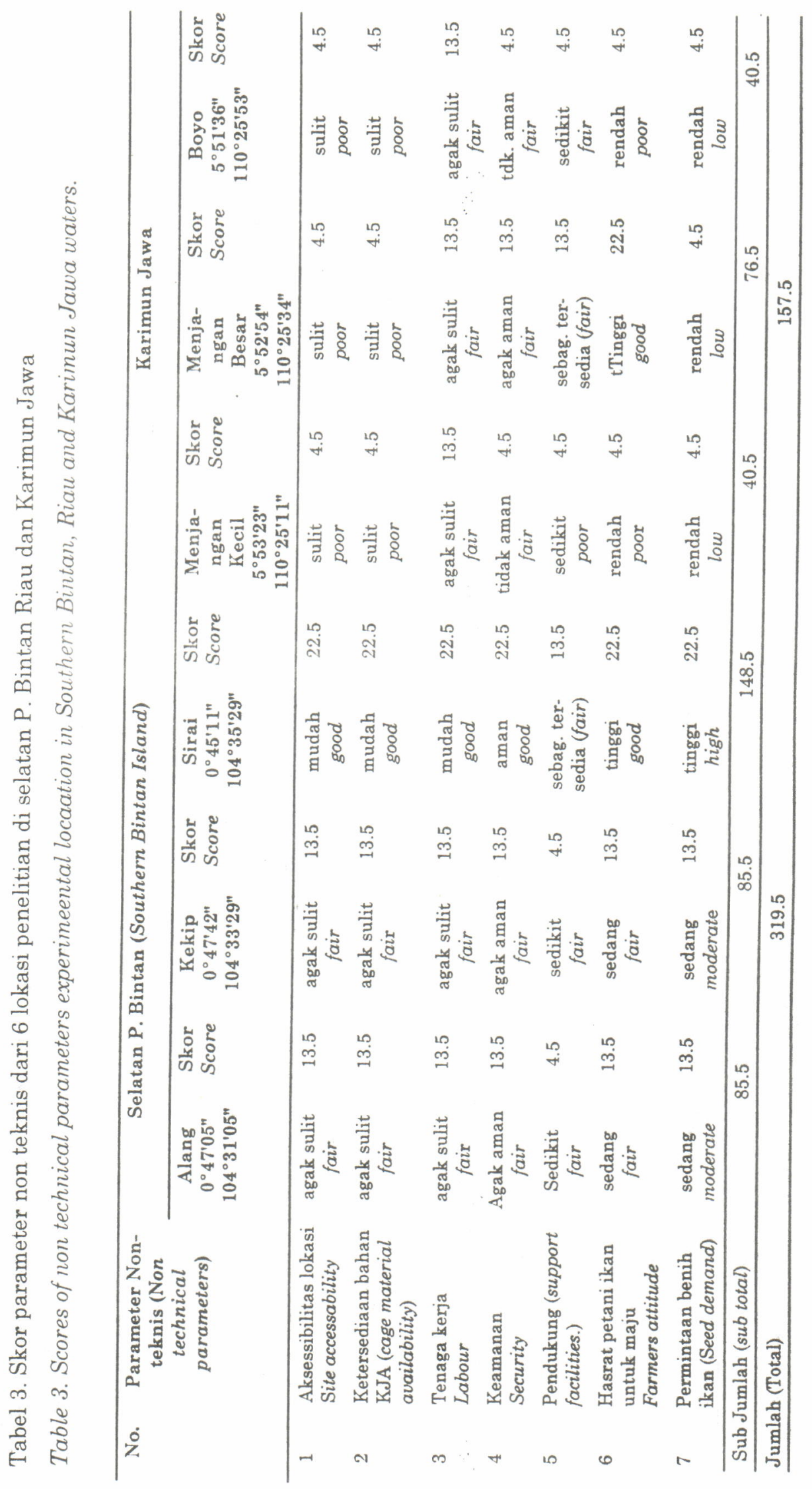


Jurnal Penelitian Perikanan Indonesia Vol.IV No.1 Tahun 1998

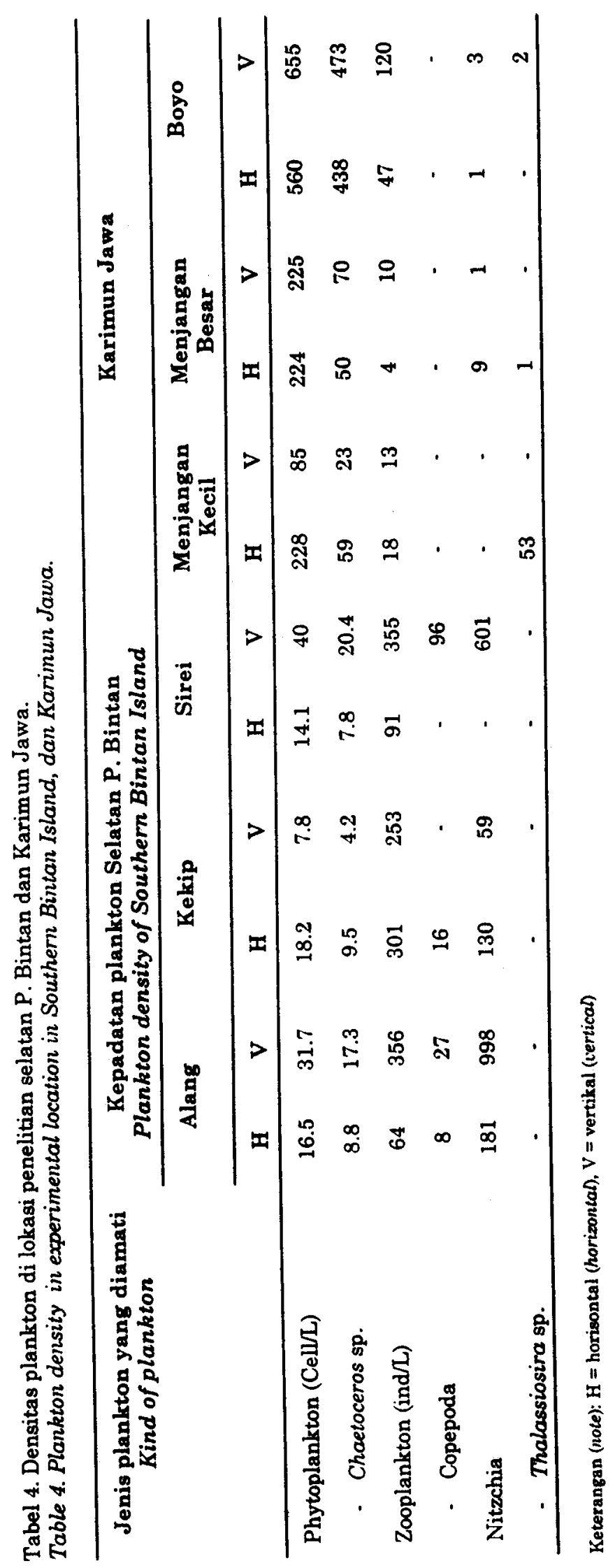




\section{KESIMPULAN DAN SARAN}

\section{Kesimpulan}

Dari penelitian identifikasi potensi lokasi bagi penempatan panti benih terapung semi alami di laut, maka dapat disimpulkan sebagai berikut:

a. Daerah Selatan P. Bintan (Kepulauan Riau) berdasarkan penelitian ini ternyata memiliki lokasi yang lebih baik untuk panti benih terapung ikan karang daripada daerah Karimun Jawa, baik ditinjau dari aspek teknis maupun nonteknis.

b. Lokasi sekitar P. Sirei yang ada di selatan P. Bintan (Kepulauan Riau) merupakan lokasi terbaik di antara lokasi-lokasi yang telah disurvai (skor 512,5), baik dibandingkan dengan lokasi lain di selatan P. Bintan (P. Alang 382,5; Kekip 393,5) sendiri maupun lokasi percobaan di Karimun Jawa (Menjangan Kecil 303,5; Menjangan Besar 363,5; Boyo 293,5). Lokasi di P. Sirei memiliki beberapa keunggulan, di antaranya adalah: terdapat pengusaha eksportir ikan kerapu, kondisi teknis dan nonteknisnya sangat menguntungkan, banyak tersedia induk-induk kerapu yang dapat dibeli dan dipesan dari pengusaha tersebut dan tersedia sarana komunikasi (telepon dan radio panggil) yang penting bagi kontrol kegiatan panti benih.

c. Untuk Kepulauan Karimun Jawa, lokasi Menjangan Besar merupakan lokasi terbaik bagi penempatan panti benih terapung semi alami ikan-ikan karang, walaupun skornya jauh di bawah lokasi P. Sirei di selatan P. Bintan, Riau.

\section{Saran}

Dari hasil penelitian ini disarankan pembangunan panti benih terapung di Sirai, selatan
P. Bintan. Namun sebelum pembangunan dilaksanakan perlu diteliti lebih rinci mengenai arus dan profil dasar pantai sehingga dapat dilakukan penempatan jangkar, serta desain dan konstruksi rakit yang tepat.

\section{DAFTAR PUSTAKA}

Asmanelli dan Masril. 1992. Survai penyakit ikan laut dalam keramba jaring apung di perairan Galang dan Batam. Sub-Balai Penelitian Budidaya Perikanan Pantai (Internal report).

Badrudin, E.M. Amin, T. Achmad dan W.Ismail. 1991. Potensi pengembangan budidaya keramba jaring apung laut di perairan Sendang Biru, Karimun Jawa, dan Teluk Banten. Bull.Pen. Perikanan Edisi Khusus no:3:1-18.

Elon Sugiri. 1995. Kondisi dan permasalahan pengendalian budidaya laut di daerah. Prosiding Temu Usaha Pemasyarakatan Teknologi Keramba Jaring Apung Bagi Budidaya Laut. Puslitbang PerikananFKPPA Agri Business Club : 253-274

Ismail.W., P.T.Imanto, B.Priono dan Lamidi. 1996. Pemilihan lokasi ideal bagi penempatan KJA reservat di perairan kep Riau, Lombok, dan Sumbawa. Jurnal Penelitian Perikanan Indonesia Vol.II no 4:1-22

Lamidi. 1992. Survei lokasi budidaya laut di perairan Bintan Selatan dan Bintan Timur Sub-Balai Penelitian Budidaya Perikanan Pantai (Internal report).

Mintardjo M.K., P. Hartono, dan Notowinarto. 1995. Prospek pengembangan budidaya laut di Kab. Bengkalis dan sekitarnya. Prosiding Temu Usaha Pemasyarakatan Teknologi Keramba Jaring Apung Bagi Budidaya Laut. Puslitbang Perikanan-FKPPA Agri Business Club : 172-178.

Sugama. K, dan A. Wijono. 1995. Teknologi pembenihan dan pengadaan benih ikan laut. Prosiding Temu Usaha Pemasyarakatan Teknologi Keramba Jaring Apung Bagi Budidaya Laut. Puslitbang Perikanan-FKPPA Agri Business Club: 120-128. 